\title{
Puderão mais os inquisidores que o rey. Las relaciones entre el Santo Oficio y la Corona en el Portugal de la Restauración (1640-1668)
}

\author{
Ana Isabel LóPEZ-SALAZAR CODES ${ }^{1}$ \\ Universidad Complutense de Madrid \\ CIDEHUS - Universidade de Évora \\ ailopezsalazar@hotmail.com
}

Recibido: 19 de junio de 2011

Aceptado: 7 de febrero de 2013

\begin{abstract}
RESUMEN
Ya en el mismo siglo XVII, políticos y religiosos consideraron el Santo Oficio luso como un aliado de la Monarquía Hispánica durante la Guerra de Restauración de Portugal. Sin embargo, esta imagen del tribunal fue creada en un contexto político muy concreto -el de los últimos años del reinado de D. João IV - y responde a unos intereses particulares. En este artículo intentaremos desentrañar cuál fue la evolución del comportamiento político del Santo Oficio a lo largo de los veintiocho años de guerra y cuáles fueron las opciones, fidelidades y vínculos con la Corona de sus miembros más relevantes, esto es, el inquisidor general y los diputados del Consejo General. Todo ello nos llevará a concluir que el Tribunal de la Fe no fue, en ningún caso, una plaza de Castilla, sino una institución que, como había hecho en el período filipino, buscó, por encima de todo, la salvaguarda de sus propios intereses.
\end{abstract}

Palabras clave: Portugal, Monarquía Hispánica, Santo Oficio, Guerra de Restauración, Inquisidor general, Consejo General.

\footnotetext{
1 Abreviaturas utilizadas: ACDF (Archivio della Congregazione per la Dottrina della Fede, Vaticano); AGS (Archivo General de Simancas); AMAAEE (Archivo del Ministerio de Asuntos Exteriores, Madrid); ANTT (Arquivo Nacional da Torre do Tombo, Lisboa); ASV (Archivio Segreto Vaticano); BA (Biblioteca da Ajuda, Lisboa); BNP (Biblioteca Nacional de Portugal, Lisboa); BNE (Biblioteca Nacional de España, Madrid); CDP (Corpo Diplomático Portugués, Lisboa, Typographia da Academia Real das Sciencias, 18621891); CG (Conselho Geral); E (Estado); EESS (Embajada Española ante la Santa Sede); FG (Fundo Geral); IE (Inquisição de Évora); RAH (Real Academia de la Historia, Madrid); SP (Secretarías Provinciales); SS (Segreteria di Stato); St. St. (Stanza Storica); TSO (Tribunal do Santo Ofício). Esta investigación fue realizada gracias a una beca de la Fundação Calouste Gulbenkian dentro del convenio con la Biblioteca Nacional de Portugal (año 2008). Asimismo, se integra en los proyectos de investigación PTDC/HIS-HIS/118227/2010 y HAR2012-37583. La cita del título ha sido extraída de la carta de Francisco de Sousa Coutinho a doña Luisa de Guzmán del 13 de agosto de 1657 (CDP, tomo XIII, pp. 450-456).
} 


\title{
Puderão mais os inquisidores que o rey. The relationships between the Holy Office and the Crown in the Portugal of the Restoration War (1640-1668)
}

\begin{abstract}
Since the Seventeenth century, politicians and clergymen considered the Portuguese Holy Office as an ally of the Hispanic Monarchy during the Restoration War. However, this image of the Holy Office was forged in a very specific political context -the end of João IV's reign- and it was conditioned by private interests. In this paper, I try to analyse, on one hand, the evolution of the Holy Office's political behaviour in the twenty eight years of war. On the other hand, I aim to consider which were the choices, fidelity bonds and connections of its most important members (namely the general inquisitor and the deputies of the General Council). I will conclude that the Inquisition was not a garrison of Castel, but instead an institution which pursued, above all, saving its own interests, as it had been done during the rule of the Habsburgs.
\end{abstract}

Key words: Portugal, Hispanic Monarchy, Holy Office, Restoration War, General Inquisitor, General Council.

\section{Introducción}

En ocasiones basta emplear una expresión impactante para que una idea quede constituida en tesis indiscutible, repetida hasta la saciedad durante generaciones. Tal fue el mérito del embajador portugués en Roma, Francisco de Sousa Coutinho, que en 1657 acertó a llamar al Santo Oficio luso "praça que nesse Reyno está ainda por conquistar e a mais perigoza que nelle temos" 2 . Las ácidas críticas del embajador al tribunal han proyectado la imagen de una Inquisición pro-castellana y enemiga del nuevo régimen Braganza. Esta tesis era corroborada, fácilmente, por la participación del inquisidor general D. Francisco de Castro en la conjura contra D. João IV descubierta en julio de 1641 y por el ambiguo comportamiento del tribunal de Évora durante la ocupación de la ciudad por don Juan José de Austria en mayo de 1663.

En líneas generales, la historiografía portuguesa más tradicional tanto progresista - encabezada por Magalhães Godinho- como conservadora - por Veríssimo Serrão-, imbuida toda ella de profundo nacionalismo, ha coincidido, precisamente, en señalar el comportamiento "antinacional" de la Inquisición lusa ${ }^{3}$. Sin embargo, cabe pregun-

2 Carta de Francisco de Sousa Coutinho a doña Luisa de Guzmán del 13 de agosto de 1657, publicada en $C D P$, tomo XIII, pp. 450-456.

3 Así, por ejemplo, según Magalhães Godinho "tudo converge no sentido de supor que a Inquisição serve objetivos políticos ligados aos meios hostis à independência portuguesa". GodinHo, V. M.: "1580 e a Restauração", en GodinHo, V. M.: Ensaios II sobre história de Portugal, Lisboa, Sá da Costa, 1978, p. 409. Cf. Serrão, J. V.: A Restauração e a Monarquia Absoluta (1640-1750), Lisboa, Verbo, 1982, pp. 145-146. Por desgracia, la tesis doctoral de Maria do Carmo Teixeira Pinto permanece sin publicar, aunque se trata del trabajo que mejor analiza las relaciones entre D. João IV y el Santo Oficio. No obstante, cabe a esta autora el mérito de haber presentado dicha relación como algo que evolucionó a lo largo del reinado y no como una realidad prefijada e invariable. Sin embargo, de forma un tanto paradójica, la autora no dejó de reproducir, en algún momento, la idea de que, tal vez, la Inquisición portuguesa habría sido partidaria de la Monarquía Hispánica durante la Guerra de Restauración. Como veremos más adelante, el Santo Oficio advirtió a D. João 
tarse hasta qué punto esta imagen del Santo Oficio como una institución contraria al gobierno de los Braganza se corresponde con la realidad. Es más, ¿hubo una política dentro de la Inquisición a favor o en contra del nuevo régimen? Y, además, ¿no evolucionaron las relaciones entre el Tribunal de la Fe y la corona durante los veintiocho años de guerra contra la Monarquía Hispánica?

A lo largo de las páginas siguientes intentaremos sustentar nuestra idea de que el Santo Oficio luso no fue, en ningún caso, una institución pro-castellana ${ }^{4}$. Existieron, sí, desavenencias profundas entre el tribunal y la corona, surgidas a raíz de la política de D. João IV con respecto a los cristãos-novos. Sin embargo, ellas no permiten afirmar que los inquisidores prefiriesen el gobierno del monarca español con el que, además, habían mantenido controversias semejantes por motivos parecidos. De hecho, desde el primer momento, hubo ministros del tribunal que apoyaron de forma decidida el movimiento restaurador, así como también hubo otros que optaron por permanecer fieles a la casa de Austria.

\section{El primero de diciembre y la participación del Santo Oficio}

El Santo Oficio no se había comportado como un bloque compacto y uniforme en el proceso de agregación de Portugal a la Monarquía Hispánica y, como es lógico, la misma división interna caracterizó la actitud de la institución ante el golpe restaurador. Es decir, algunos ministros apoyaron decididamente al Braganza; otros se exiliaron a Castilla y otros, quizás la mayoría, esperaron atentos el devenir de los acontecimientos 5 .

Así, entre los portugueses que prepararon el golpe de Estado del 1 de diciembre de 1640 se encontraban varios miembros del tribunal de Lisboa, como los inquisidores

IV de que Felipe IV podía utilizar en provecho propio las disputas sobre la jurisdicción real para eximir de la pena de confiscación de bienes a los condenados por herejía. Según Teixeira Pinto, esta preocupación del tribunal "não deixa de ser curiosa vinda de uma instituição cuja ligação com a monarquia castelhana tem sido sublinada". Por otra parte, cuando analizó las causas del conflicto entre la Inquisición y la Compañía de Jesús después de la Restauración, Teixeira Pinto consideró que una de ellas sería el apoyo de los jesuitas a la casa de Braganza. Esta vinculación de los jesuitas a los Braganza, desde tiempos de los Austrias, habría contribuido "para um extremar das posições entre a instituição inquisitorial, encabeçada por D. Francisco de Castro, apoiante dos Filipes, e a Companhia". Pinto, M. C. T.: Os cristãos-novos de Elvas no Reinado de D. João IV. Hérois ou Anti-Hérois, tesis doctoral inédita, Lisboa, Universidade Aberta, 2003, pp. 122 y 135.

4 Ya hace años, el profesor Rafael Valladares apuntó con acierto que el Santo Oficio defendía, sobre todo, sus propios intereses y que, precisamente por ello, podía comportarse tanto como una institución pro-filipina como pro-bragancista, dependiendo de las circunstancias concretas de cada momento. VALLADARES, R.: La rebelión de Portugal. Guerra, conflicto y poderes en la Monarquía Hispánica (1640-1680), Valladolid, Junta de Castilla y León, 1998, p. 243.

5 Recientemente, Ângela Barreto Xavier y Pedro Cardim han llamado la atención sobre la tendencia a estudiar el comportamiento político de las instituciones de un modo colectivo, como si en su seno todos los miembros mantuviesen las mismas opiniones. Xavier, Â. B. y CARDim, P.: D. Afonso VI, Lisboa, Temas e Debates, 2008, p. 146. Sobre la actitud del Santo Oficio y de sus ministros durante la unión de Portugal a la Monarquía Hispánica, vid. LóPez-SalazAR CODES, A. I.: Inquisición y política. El gobierno del Santo Oficio en el Portugal de los Austrias (1578-1653), Lisboa, CEHR-UCP, 2011, pp. 311-326. Sobre las relaciones entre la monarquía y el clero portugués a principios de la Unión Dinástica, vid. Palomo, F.: "Para el sosiego y quietud del reino. En torno a Felipe II y el poder eclesiástico en el Portugal de finales del siglo XVI", Hispania, vol. LXIV/1, n. 216 (2004), pp. 63-94. 
Pantaleão Rodrigues Pacheco, canónigo doctoral de la catedral lisboeta, y Diogo de Sousa, arcediano de Braga, y el diputado Estévão da Cunha. Si hemos de dar crédito a los relatos de la época, este Estévão da Cunha habría constituido el vínculo entre los conjurados y los dirigentes populares descontentos con el gobierno filipino ${ }^{6}$. Además, estos miembros del Santo Oficio estaban estrechamente emparentados con algunos de los llamados cuarenta fidalgos que aclamaron a D. João IV. Así, Diogo de Sousa era hermano de Tomé de Sousa, mientras que Estévão da Cunha era primo de los hermanos Francisco de Melo, monteiro-mor, y Jorge de Melo?.

Pero también hubo ministros de la fe que optaron por permanecer fieles a Felipe IV y abandonar Portugal. Estos portugueses -al igual que los catalanes contrarios a la secesión del Principado- recibieron socorros y otras mercedes del monarca ${ }^{8}$. Entre los exiliados a Castilla destaca D. Luís de Melo, diputado del Consejo General del Santo Oficio. Melo era deán de Braga y hermano del secretario de Estado Miguel de Vasconcelos. Al día siguiente de la aclamación, su casa fue saqueada, pero D. Luís de Melo y su hermano D. Pedro Barbosa de Eça, obispo de Leiria, lograron huir de Portugal, disfrazados de frailes ${ }^{9}$. En Madrid, el obispo de Leiria buscó el amparo de la Hermandad de San Antonio de los Portugueses, que le ofreció alojamiento en su hospital ${ }^{10}$. Por su parte, Felipe IV hizo merced a D. Luís de Melo -que ingresó en dicha hermandad de San Antonio- del curato de Jorquera, en el obispado de Cartagena, con retención del deanato de la catedral de Braga ${ }^{11}$. Todo parece indicar que conceder al deán de Braga el curato de Jorquera, en la actual provincia de Albacete, era una forma de alejarle de la corte, en un momento, además, en el que había caído su antiguo valedor, el conde duque de Olivares. Pero no contamos con ningún dato que nos permita afirmar que Melo llegó a trasladarse al pueblo manchego.

También optaron por el exilio D. Álvaro de Ataíde y António da Silveira, inquisidores de Lisboa y de Évora, respectivamente. D. Álvaro, canónigo magistral de la catedral de Lisboa, era hijo de D. António de Ataíde, conde de Castro Daire y antiguo gobernador de Portugal. También su hermano, D. Jerónimo de Ataíde, conde de Castanheira y de Castro Daire, permaneció fiel a Felipe IV, que le otorgó el título de marqués de Colares ${ }^{12}$. El monarca hizo merced al antiguo inquisidor de Lisboa de una dignidad en la catedral de Toledo. Pero Ataíde murió en 1642, durante la jornada del

6 MAIA, P. Nicolau da (atribuido): Relação de tudo o que passou na felice aclamação do mui alto e mui poderoso rey Dom Ioão o IV nosso senhor, Lisboa, a custa de Lourenço de Anveres, 1641, pp. 8 y 24.

7 Moraes, C. A. de: Pedatura Lusitana, Oporto, Liv. Fernando Machado, 1945, tomo III, vol. I, pp. 472473. Sobre las relaciones de parentesco de los cuarenta fidalgos, vid. Costa, L. F. y CunHA, M. S. da, D. João $I V$, Lisboa, Temas e Debates, 2008, p. 341.

8 Sobre esta cuestión, vid. Valladares, R.: "De ignorancia y lealtad. Portugueses en Madrid, 1640-1670", Torre de los Lujanes, 37 (1998), pp. 133-150.

9 Seyner, fray António (O.S.A.): Historia del levantamiento de Portugal, Zaragoza, por Pedro Lanaja y Lamarca, 1644, pp. 59-60. RAH, Salazar y Castro, C-35, 9/258: Portugal tyranizado por Don Juan de Bragança y su desatino... remitido por un portugués de Lisboa a otro residente en la corte. Traducido de su lengua en la castellana (1643).

10 Pulido Serrano, J. I.: "La Hermandad y Hospital de San Antonio de los Portugueses de Madrid", Anales del Instituto de Estudios Madrileños, XLIV (2004), pp. 299-230.

11 Archivo de San Antonio de los Portugueses (Madrid), lib. 515, nº 2. AMAAEE, EESS, leg. 96, fol. 143: Carta de Felipe IV al duque de Terranova, embajador español en Roma, del 19 de octubre de 1655.

12 Moraes, op. cit. (nota 7), tomo IV, vol. 2, p. 18. 
rey a Zaragoza ${ }^{13}$. Por su parte, António da Silveira, canónigo doctoral de Guarda, era hijo de João Freire, señor de Bobadella y Azinhal, y de doña Guiomar da Silveira ${ }^{14}$. En 1635, después de ocho años como inquisidor de Évora, se había trasladado a Madrid para requerir una merced que, al parecer, nunca llegó debido a la enemistad con el secretario de Estado Diogo Soares. Cuando estalló la rebelión de Portugal, Silveira decidió permanecer en Madrid y Felipe IV le concedió un socorro de 800 reales al mes, aumentados después a $1.000^{15}$.

Asimismo permanecieron fieles a Felipe IV otros dos ministros del Santo Oficio portugués: el doctor Francisco Paez Ferreira y el licenciado Simão Lobo Barbosa, comisarios de la Inquisición en Río de Janeiro y Ceuta, respectivamente. El comisario de Ceuta se trasladó a Madrid nada más iniciarse la rebelión de Portugal y el monarca le hizo merced de una canonjía en Baeza ${ }^{16}$. Y el de Río de Janeiro optó por Felipe IV en 1647, después de haber servido algún tiempo al Braganza ${ }^{17}$.

Por su parte, quienes apoyaron desde el primer momento a D. João IV fueron recompensados. Quizás no sea casual que los dos primeros inquisidores que accedieron al Consejo General tras la Restauración fuesen los ya citados Pantaleão Rodrigues Pacheco, en enero de 1641, y Diogo de Sousa e Castro, en septiembre de 1642. Como sabemos, ambos habían participado en el golpe restaurador y D. João IV los premió con los obispados de Elvas, a Rodrigues Pacheco, y de Leiria, a Sousa e Castro. También secundó rápidamente al Braganza Sebastião César de Meneses, que ejerció de secretario del estado de la nobleza en las Cortes de enero de 1641. Por ello, en 1642, D. João IV le hizo merced del obispado de Oporto y en 1649 del de Coimbra ${ }^{18}$.

\section{Las relaciones entre el Santo Oficio y la corona antes de 1649}

El Santo Oficio inició el primer año del Portugal restaurado con debates sobre la conveniencia de conceder un nuevo edicto de gracia a los cristãos-novos. En enero de 1641, el Consejo General ordenaba al tribunal de Évora que elevase una consulta sobre este asunto. Resulta en extremo interesante uno de los motivos alegados por los miembros del tribunal alentejano para no otorgar el edicto de gracia. En su opinión, la Inquisición había concedido los edictos anteriores $-\mathrm{y}$ no olvidemos que tenían en

13 RAH, Salazar y Castro, C-35, 9/258: Portugal tyranizado..., fols. 195-196.

14 Moraes, op. cit. (nota 7), tomo II, vol. 2, p. 22.

15 AGS, E, leg. 7041, doc. 54: Consulta de la Junta de Inteligencias de Portugal del 24 de julio de 1642. AGS, SP, Portugal, lib. 1583, fols. 454-457v: Memorial de António da Silveira y billete de Felipe IV a fray Antonio de Sotomayor del 31 de enero de 1644.

16 AGS, SP, Portugal, lib. 1528, sin fol.: Billete para don Jerónimo de Villanueva del 13 de abril de 1643.

17 AGS, SP, Portugal, leg. 2646, sin fol.: Memorial del doctor Francisco Paez Ferreira (1652).

18 En 1649, Sebastião César de Meneses, electo obispo de Coimbra, se comprometía a que el papa impusiese en ese obispado una pensión de de 8.000 cruzados anuales para el infante D. Afonso, además de la habitual (del valor de un cuarto de las rentas) para las personas que nombrase el rey. ANTT, Colecção São Vicente, liv. 12, fols. 314-316: Procuración de Sebastião César de Meneses en las personas de fray Manuel Álvares Carrilho, Nuno da Cunha, S. J., y Francisco Nunes Sanches (6 de abril de 1649). Cf. BASTo, A. de M.: "D. Sebastião César de Meneses. Bispo-Eleito do Porto (1642-1649)", Trabalhos da Associação dos Arqueólogos Portugueses, V (1941), pp. 89-104. Matos, G. de M.: "Nos bastidores da política seiscentista", Trabalhos da Associação dos Arqueólogos Portugueses, V (1941), pp. 56. 
mente el de 1627- para justificarse ante los reyes y hacer frente a las críticas de los conversos. Los propios monarcas pidieron que se concediesen por consejo de sus ministros castellanos, aficionados y vinculados a los cristãos-novos. Sin embargo, en 1641, según señalaban los inquisidores de Évora, ya había desaparecido este motivo, gracias a la Restauración. En este momento, el Santo Oficio de Evora parecía afrontar con optimismo la nueva época que ahora se abría:

Deus deo a este reino rey natural que trata de conservar a pureza de nossa sancta fe catholica, que conhece seus ministros e sabe a verdade e inteireza com que tratão os negocios que tem a sua conta e não necessitão de outras justificaçoins ${ }^{19}$.

Sin embargo, las relaciones entre el Santo Oficio y la corona no tardarían en enfriarse. En 1641 tuvo lugar la conjura pro-filipina en la que participó el inquisidor general D. Francisco de Castro. La trama fue descubierta y el 28 de julio Castro era encarcelado ${ }^{20}$. Aunque, según parece, la participación del inquisidor general en esta conjura fue más bien reducida, se difundió la noticia de que los conspiradores guardaban la pólvora en el palacio de los Estaus, sede del tribunal de Lisboa y de los organismos de gobierno del Santo Oficio ${ }^{21}$. Según la Historia del levantamiento de Portugal de fray António Seyner, el Braganza habría intentado que, una vez encarcelado, el inquisidor general renunciase a su oficio para poder nombrar a otra persona de su agrado ${ }^{22}$. No obstante, D. Francisco de Castro decidió mantenerse en el cargo y tuvo más suerte que otros conjurados - como el marqués de Vila Real y el duque de Caminha- pues, tras pasar casi dos años en prisión, fue puesto en libertad en marzo de 1643. Para celebrarlo, el tribunal de Évora organizó una solemne procesión hasta el convento de Santo Domingo de la ciudad.

Según parece, también en 1641 el decano del Consejo General, fray João de Vasconcelos, fue desterrado de la corte por orden de D. João IV. Las noticias sobre este acontecimiento son muy escasas pero, a pesar de la parquedad de las fuentes, sabemos que el motivo fue un sermón de Vasconcelos, predicado en la catedral de Lisboa, en el que criticaba la recepción en Portugal de una embajada procedente de Holanda $^{23}$. Quizás se trate de la del almirante Adriano Gyzels que llegó a Lisboa al mando de una armada destinada a unirse a las de Portugal y Francia en septiembre

19 BNP, FG, cód. 1536, fols. 107r-110v: Orden del Consejo General y consulta del tribunal de Évora del 28 de enero de 1641.

20 Sobre esta conjura, vid. Valladares, op. cit. (nota 4), pp. 39-40; Costa y Cunha, op. cit. (nota 7), pp. $139-156$

21 AGS, E, Portugal, leg. 7041, doc. 107: Consulta de la Junta de Inteligencias de Portugal del 16 de septiembre de 1641 .

22 No obstante, debemos tener en cuenta que fray António Seyner era contrario al golpe restaurador. SEYNER, op. cit. (nota 9), pp. 209-210.

23 Muchos años más tarde, Sousa Coutinho recordaba este incidente: "Com capa de zello pio e christão tratarão sempre os Inquizidores desde o prencipio do novo reynado incaminhalo para a sua ruina, quando por quatro olandezes forão a elle, (sic) pregou na sé dessa Corte frei João de Vasconcellos tão livremente que obrigou a Sua Magestade a desterralo". Carta de Francisco de Sousa Coutinho a doña Luisa de Guzmán del 13 de agosto de 1657, publicada en $C D P$, tomo XIII, pp. 450-456. 
de $1641^{24}$. Como es lógico, esta actitud de Vasconcelos fue muy alabada por aquellos portugueses contrarios al nuevo régimen Braganza. Uno de ellos transmitía de este modo, quizás un tanto exagerado, la noticia a Madrid:

al reverendo y venerable padre maestro fray Juan de Vasconcelos [...] tuvo preso y le privó del officio de predicador de Su Magestad cathólica, por haver dicho en el púlpito con zelo evangélico lo que convenía a la honra de Jesu Christo y pureza de su santa fee, y religion catholica, que el tirano ha puesto en notorio riesgo con la introducción de tantos hereges y con su rebelión ${ }^{25}$.

Desde luego, el Santo Oficio no podía ver con buenos ojos el capítulo de la tregua entre Portugal y Holanda que hacía referencia a las cuestiones religiosas. Como es sabido, Tristão de Mendoça Furtado, embajador de D. João IV en las Provincias Unidas, había firmado una tregua con los Estados Generales el 12 de junio de 1641. En el capítulo 26 del tratado se establecía que los naturales de las Provincias Unidas, siempre que fuesen cristianos, podrían gozar de libertad de conciencia en Portugal y practicar libremente su religión dentro de los navíos. Es más, los embajadores o ministros enviados a Portugal tendrían derecho a realizar las ceremonias religiosas dentro de sus casas. Antes de ratificar la tregua, D. João IV ordenó la constitución de una junta para estudiar este capítulo y para analizar si difería de lo establecido en el tratado de alianza de 1630 entre España y Gran Bretaña. Estaba presidida por D. Rodrigo da Cunha, arzobispo de Lisboa, e integrada por Sebastião César de Meneses y Pedro da Silva de Faria, diputados del Consejo General, el capelão-mor D. Álvaro da Costa, Cristóvão de Távora, los padres Diogo de Heredia y Nuno da Cunha y fray Manuel Rebelo. El 24 de septiembre, la junta enviaba su parecer al monarca. Como era de esperar, estos eclesiásticos se opusieron frontalmente a dicho capítulo de la tregua entre Portugal y Holanda y aconsejaron que se adecuase a lo acordado en 1630 con Gran Bretaña. No obstante y pese a todo, el tratado fue ratificado por D. João IV en noviembre de ese mismo año ${ }^{26}$.

También se opuso el Santo Oficio a que, para solucionar el problema de la provisión de los obispados, los cabildos, a propuesta del monarca, eligiesen a los prelados que serían luego confirmados por los metropolitanos. Según el conde de Ericeira, en 1647 D. João IV, por medio del padre Nuno da Cunha, habría presentado al Sumo Pontífice un documento en el que amenazaba con recurrir a este arbitrio. Sin embargo, el Santo Oficio portugués se habría opuesto a este medio, de modo que el papa habría afirmado "que a Inquisição de Portugal o livrara de hum grande cuydado"27.

24 Bocage, C. R. du: Subsidios para o estudo das relações exteriores de Portugal em seguida à Restauração (1640-1649), Lisboa, Academia das Sciencias de Lisboa, 1916, volumen 1, pp. 110-111.

25 RAH, Salazar y Castro, C-35, 9/258: Portugal tyranizado..., fol. 148.

26 "Documentos relativos à nomeação de uma junta para examinar os artigos religiosos dos tratados com a Inglaterra e a Hollanda", publicados por BocAGE, op. cit. (nota 24), pp. 199-204.

27 Meneses, Luís: História de Portugal Restaurado, Lisboa, oficina de João Galrão, 1679, tomo I, pp. 635-638. 
Como bien señaló António Antunes Borges, la intervención del Santo Oficio en esta polémica no tuvo lugar en 1647 sino en $1650^{28}$. A lo ya dicho por Borges podemos añadir un par de datos que vienen a confirmar su tesis. Como es sabido, en 1649 se publicaron en Lisboa dos textos en los que se sostenía que, ante la actitud del papa, D. João IV podía elegir obispos y ordenar a los metropolitanos que los confirmasen. Según el embajador Sousa Coutinho, la aparición de estos escritos coincidió con la celebración de la congregación general de la Compañía de Jesús y, aunque algunos castellanos pidieron a los jesuitas que contradijesen la opinión de los doctores de la Sorbona, ninguno quiso oponerse a su doctrina. Sin embargo, los inquisidores portugueses decidieron condenarla y el Consejo General prohibió ambos escritos por un decreto del 12 de marzo de 1650. Fue entonces cuando, quizás, Inocencio X pudo afirmar aquello de que "devia aos inquizidores livraremno de huma opreção" 29 .

Ahora bien, a pesar de estos episodios concretos, del castigo de fray João de Vasconcelos y de la prisión de D. Francisco de Castro, durante los primeros años de la Restauración las relaciones entre el Santo Oficio y el régimen Braganza no se caracterizaron, ni mucho menos, por el enfrentamiento o la desconfianza. D. João apoyó al tribunal en el sonado pleito que mantuvo con los jesuitas de la Universidad de Evora ${ }^{30}$. Y, por su parte, el Santo Oficio decidió colaborar con el nuevo régimen tanto en las cuestiones económicas como militares. A fin de preservar los privilegios de los miembros del Santo Oficio y, al mismo tiempo, de contribuir a la defensa del reino, el inquisidor general creó una compañía de familiares. De hecho, el Consejo acordó retirar la carta de familiar del Santo Oficio a un tal Bartolomeu Soeiro porque no había querido acudir a los alardes de esta compañía ${ }^{31}$. Y, desde el punto de vista económico, el Santo Oficio aceptó también el nuevo impuesto de las décimas. Como es sabido, este tributo fue votado en las primeras Cortes del Portugal restaurado y suponía un décimo del valor de la hacienda de cada uno de los vasallos del reino, sin que quedasen exceptuados los estamentos privilegiados ${ }^{32}$. En un principio, el Consejo General dispuso que todos los ministros del tribunal pagasen la décima de sus salarios y bienes. No obstante, más tarde, la Inquisición se comprometió contribuir

28 Borges, A. A.: "Provisão dos bispados e concílio nacional no reinado de D. João IV”, Lusitania Sacra, III (1958), pp. 95-105.

29 Los textos publicados en 1649 y que fueron condenados por el Santo Oficio son: Pro parte Ordinum Regni Portugalliae Proponitur Academiae y Responsum Praecipuorum Doctorum Parisiensis Academiae Sorbonicae. ACDF. St. St. BB 5-c: Edicto del Consejo General del Santo Oficio del 12 de marzo de 1650. Cf. Carta de Francisco de Sousa Coutinho a doña Luisa de Guzmán del 13 de agosto de 1657, publicada en CDP, tomo XIII, pp. 450-456. La congregación general de la Compañía de Jesús a que se refería Sousa Coutinho es la que se celebró tras la muerte de Vincenzo Caraffa y de la que salió elegido general Francisco Piccolomini.

30 Sobre esta cuestión, vid. Correia, P. L. R.: "O caso do padre Francisco Pinheiro: estudo de um conflito entre a Inquisição e a Companhia de Jesus no ano de 1643”, Lusitania Sacra, 2a série, 11 (1999), pp. 295 - 322.

31 ANTT, TSO, CG, liv. 348, fol. 12v: Orden del Consejo General del 23 de agosto de 1641. Cf. la carta de D. Francisco de Castro a D. João IV del 14 de octubre de 1643, publicada por BAIÃo, A.: "El-Rei D. João IV e a Inquisição", Anais da Academia Portuguesa da História, 6 (1942), pp. 24-26.

32 Sobre este tributo, vid. Magalhães, J. R.: "Dinheiro para a guerra: as décimas da Restauração", Hispania, LXIV/1, n. 216 (2004), pp. 157-182, y Costa y CunHA, op. cit. (nota 7), pp. 249-251. 
con un servicio voluntario de 1.000 cruzados anuales a cambio de que sus ministros quedasen exentos de pagar la décima de los sueldos que recibían del Santo Oficio ${ }^{33}$.

Además, el Santo Oficio, como tribunal, celebró la Restauración. Ambos poderes, la Inquisición y la corona, se presentaron juntos en varias ocasiones. Así, por ejemplo, durante la jornada de D. João IV al Alentejo, en julio de 1643, la Inquisición de Évora fue a besarle la mano y a rendirle homenaje. En esta ceremonia, el tribunal se hizo acompañar no sólo por los familiares de la ciudad de Évora, sino también por aquellos otros que habían venido en el cortejo real y que, como es lógico, pertenecían a la nobleza ${ }^{34}$. Asimismo, los monarcas y sus hijos asistieron a los autos de fe celebrados en Lisboa. El 6 de abril de 1642 tenía lugar el primer auto público del Portugal restaurado en el Terreiro do Paço. A él asistieron todos los miembros de la familia real: los reyes, el príncipe D. Teodósio y las infantas. El encargado de predicar fue el padre Bento de Siqueira, de la Compañía de Jesús, que en el sermón -realmente parco en alusiones políticas- no dejó de hacer referencia a la restauración de la corona en los Braganza:

Poderase descontar por huma, \& principal das grandes felicidaes, que Deos deu, \& ha de dar a Vossas Magestades na entrada milagrosa de seus venturosos Reynos, esta de sahir a publico pello credito da feè, \& cresença do Rey dos Reys, no Auto, em que o zelo do Tribunal Apostolico trata de tirar a limpo sua honra, \& divinidade ${ }^{35}$.

La celebración del nuevo régimen -"restauração de nossa perdida liberdade"- resultó mucho más evidente en el sermón del auto de fe del 25 de junio de 1645, al que asistió, de nuevo, toda la familia real. Era éste un auto especial, pues en él hubo once relajados en carne, ocho de los cuales lo fueron por sodomía ${ }^{36}$. El padre agustino fray Filipe Moreira, que pronunció el sermón, pudo con facilidad echar mano de unas palabras del salmista en las que festejaba la llegada del Rey-Mesías que habría de castigar con fuego a los infames ${ }^{37}$. Moreira identificó, claro está, el advenimiento del Mesías con la restauración del trono portugués en la persona del duque de Braganza. Además, el agustino recurrió a elementos de clara raigambre sebastianista para referirse tanto a Cristo como a D. João IV, a quienes podían aplicarse los apelativos de "rey pacifico, desejado, \& encuberto" 38 .

33 ANTT, TSO, CG, liv. 348, fol. 13r: Orden del Consejo General del 12 de noviembre de 1641. ANTT, TSO, CG, maço 27, nº. 100: Provisión de D. João IV del 18 de abril de 1643.

34 Forma em que a Inquisição de Evora foi beijar a mão ao senhor rei Dom João o quarto quando foi aquella cidade, documento publicado por BAIÃO, op. cit. (nota 31), pp. 11-70.

35 Sermam que pregou o padre mestre Bento de Siqueira da Companhia de Iesu no auto da fé, Lisboa, na officina de Domingos Lopes Rosa, 1642, p. 1.

36 Moreira, A. J.: História dos principais actos e procedimentos da Inquisição em Portugal, Lisboa, Imprensa Nacional Casa da Moneda, 1980 [1845], parte II.

37 "Pones eos ut elibanum ignis in tempore vultus tui: Dominus in ira sua, conturbabit eos et devorabit eos ignis" (Tú los podrás como en un horno de fuego al mostrarles tu cara. El Senhor, en su ira, los conturbará y el fuego los devorará). Salmos, 20, 10.

38 Sermão que pregou o P.M. Fr. Philippe Moreira [...] no auto da fe, que se celebrou no Terreiro do Paço, Lisboa, na officina de Domingos Lopes Rosa, 1646. Entre el auto celebrado en el Terreiro do Paço en abril de 1642 y el de junio de 1645 hubo otro, en julio de 1644, en el que predicó el diputado del Consejo General 
Dos años más tarde era el franciscano fray João de São Bernardino el encargado de predicar en el auto de fe del 15 de diciembre de 1647. Aunque no se conserva su sermón, podemos intuir que, de haber en él alusiones políticas, no serían, desde luego, contrarias al nuevo régimen. Baste recordar que fray João había sido el primer religioso que predicó en la capilla real ante el nuevo rey D. João IV con motivo de la fiesta de la Inmaculada, el 8 de diciembre de 1640, y que al día siguiente, segundo domingo de Adviento, lo haría en la catedral de Lisboa ${ }^{39}$

\section{El albalá de 1649: el enfrentamiento entre el Tribunal y la corona}

Como vemos, durante los primeros años del Portugal restaurado, el Santo Oficio no fue, ni mucho menos, una fortaleza de Castilla. Como ya señaló Maria do Carmo Teixeira Pinto, la ruptura entre el Tribunal de la Fe y el régimen Braganza se produjo a raíz de la fundación de la Compañía de Comercio de Brasil y del conocido albalá de exención de confiscaciones de 1649. Sería osado por nuestra parte y, además, no es el objetivo del presente trabajo analizar la génesis de la Compañía y dilucidar el papel desempeñado por el padre António Vieira. Nos interesa sólo estudiar el proceso de distanciamiento entre el Santo Oficio y la corona y los argumentos empleados por el primero para cuestionar la jurisdicción del monarca sobre los bienes confiscados ${ }^{40}$.

El 25 de julio de 1647, el Consejo General se reunía para consultar sobre cierto arbitrio presentado al monarca. En él se consideraba que uno de los medios para fomentar el comercio luso era exceptuar de la pena de confiscación de bienes el dinero y la hacienda de los mercaderes. Lo interesante de esta consulta no es la lógica oposición del tribunal a tal medida, sino el argumento empleado para hacerle frente. Los diputados sostenían ahora, como ya habían hecho en tiempos de los Felipes, que los monarcas carecían de jurisdicción para eximir a los condenados por el Santo Oficio de la pena de confiscación de bienes que imponía el Derecho. Además, advertían al monarca de que, si finalmente se concedía esta gracia a los cristãos-novos, el Santo Oficio intentaría por todos los medios conseguir su revocación y procedería contra los autores de tal medida como si se tratase de cómplices de herejes ${ }^{41}$. Al año siguiente, los tres tribunales de distrito, en sus respectivos pareceres, concordaron con lo

fray João de Vasconcelos. Desgraciadamente, su sermón no llegó a imprimirse ni, que sepamos, se conserva ejemplar alguno manuscrito.

39 En ambos sermones, fray João de São Bernardino se encargó de justificar la Restauración. Machado, D. B.: Bibliotheca Lusitana, Lisboa, por António Isidoro da Fonseca, Ignacio Rodrigues y Francisco Luiz Ameno, 1741-1759, vol. 2, pp. 610-612. Sobre el sermón predicado por fray João de São Bernardino el día de la Inmaculada de 1640, vid. Costa y CunHA, op. cit. (nota 7), pp. 247.

40 Sobre estas cuestiones, vid. Pinto, op. cit. (nota 3), pp. 104-125, y Azevedo, J. L. de: História dos cristãos-novos portugueses, Lisboa, Clássica Editora, 1989 [1921], pp. 244-247. Sobre la Compañía General de Comercio de Brasil, vid. Costa, L. F.: O transporte no Atlântico e a Companhia Geral do Comércio do Brasil 1580-1663), Lisboa, CNCDP, 2002.

41 BNP, FG, cód, 1538, fols. 269r-274v: Relação do que o Santo Officio tem obrado a fim de encontrar a resolução que Sua Magestade tem tomado sobre o izentar os hereges da pena de confiscação. El autor de esta relación es Diogo Velho, secretario del Consejo General. Sobre este arbitrio presentado en 1647, vid. PINTO, op. cit. (nota 3), pp. 104-117, y AzEvedo, op. cit. (nota 40), pp. 246-247. Azevedo dudó de que este arbitrio fuese, como se ha pensado, de Vieira. 
apuntado por los del Consejo ${ }^{42}$. Y el 1 de diciembre de 1648, el inquisidor general volvió a convocar a los diputados del Consejo para estudiar qué debía hacer el Santo Oficio en caso de que el rey concediese, por ley, la exención de confiscaciones a los cristãos-novos. En la reunión estuvieron, junto a D. Francisco de Castro, todos los miembros del Consejo: fray João de Vasconcelos, Pero da Silva de Faria, Francisco Cardoso de Torneo, Sebastião César de Meneses, Pantaleão Rodrigues Pacheco y Diogo de Sousa. Ese mismo día -aniversario de la Restauración- todos se comprometieron solemnemente a declarar nula tal ley y a proceder contra quienes intentasen ejecutarla ${ }^{43}$. Por lo tanto, como vemos, en 1647 y 1648, aparecía ya perfilada la que sería la respuesta del Tribunal de la Fe al albalá de 1649.

A pesar de la firme oposición del Santo Oficio -que los diputados y el inquisidor general manifestaron personalmente a D. João IV el 6 de febrero de 1649- el día 9 el rey firmaba un albalá por el que eximía de la confiscación de bienes a los cristãosnovos condenados por judaísmo. Lógicamente, la respuesta del tribunal no se hizo esperar y el 5 de marzo el Consejo General elevó una consulta al monarca. Sin embargo, en vez de enfrentarse directamente a la corona, optó por recurrir a medios más sutiles. Así, recordó al soberano su interés en que la Santa Sede le reconociese como rey legítimo de Portugal y le advirtió de que, ahora, Felipe IV podría persuadir al pontífice de que D. João usurpaba la jurisdicción papal al eximir a los herejes de la confiscación ${ }^{44}$. Por otra parte, el Consejo ordenó, de momento, suspender las prisiones a fin de evitar tanto el acatamiento como la desobediencia al albalá regio ${ }^{45}$.

Al mismo tiempo, el inquisidor general y el Consejo decidieron aunar fuerzas y buscar el apoyo de los tres tribunales de distrito. Por ello, les ordenaron que debatiesen si el Santo Oficio debía declarar nulo el albalá, proceder contra sus ejecutores, recurrir al papa, aun sin permiso del monarca, y suspender las prisiones o llevarlas a cabo sin el secuestro de los bienes ${ }^{46}$. En realidad, como vemos, lo que estaba en juego era el derecho del Tribunal de la $\mathrm{Fe}$ a desobedecer los mandatos regios en un momento, además, especialmente complicado debido a la guerra contra la Monarquía Hispánica y a la renuencia de la Santa Sede a reconocer a D. João IV como rey de Portugal. Por ello, la Inquisición tuvo que hacer encaje de bolillos. Así, aunque la mayoría de los inquisidores y diputados coincidieron en que el tribunal podía declarar nulo el albalá y proceder contra sus ejecutores, recordaron al mismo tiempo que no era conveniente porque podía redundar en perjuicio del propio Santo Oficio. Como señaló el tribunal de Évora, ello sería una "occasião de irritar o animo do dito senhor [D. João $I V]$ e causa de alguma grande perturbação ao Santo Oficio e se arriscar muito a authoridade delle que principalmente se conserva por meyo da benevolencia e

42 BNP, FG, cód, 1538, fols. 267r-268r: Parecer de Alexandre da Silva del 18 de febrero de 1648.

43 ANTT, TSO, CG, liv. 346, fol. 26v-27r: Asiento del Consejo General del 1 de diciembre de 1648.

44 BNP, FG, cód. 1538, fols. 269r-274v: Relação do que o Santo Officio tem obrado... (consulta del Consejo General del 5 de marzo de 1649).

45 Como señalaron los diputados, si al realizar la prisión se ejecutaba el secuestro de los bienes, el Santo Oficio estaría contraviniendo la orden real pero, si no se secuestraban, la Inquisición se estaría conformando tácitamente con el albalá del 9 de febrero.

46 BNP, FG, cód. 1538, fol. 175r: Apontamentos ou propostas sobre cada hum dos quais se ha de votar em mesa. Ibidem, fols. 276r-287v: Consultas de los tribunales de Coimbra (sin fecha), Évora (30 de julio de 1649) y Lisboa (3 de agosto de 1649). 
favor do principe". Más divisiones generó entre los ministros la cuestión de recurrir al papa sin licencia del monarca. Así, mientras el tribunal de Coimbra sostuvo que el Santo Oficio podía dar cuenta de todo al pontífice aun sin permiso del rey, el de Evora consideró lo contrario ${ }^{47}$. También entre los ministros de la Inquisición de Lisboa hubo diversidad de pareceres. Los tres inquisidores y gran parte de los diputados mantuvieron que el Santo Oficio debía recurrir al papa, con o sin licencia del monarca. Por el contrario, un sector minoritario de los diputados del tribunal lisboeta se opuso por motivos políticos, pues consideró que serviría para enfrentar al rey de Portugal con el papa y, en último término, para favorecer al monarca católico ${ }^{48}$.

Finalmente, D. Francisco de Castro decidió acudir al papa, al que pidió que determinase cómo debía comportarse el Santo Oficio en este asunto ${ }^{49}$. Como es sabido, el 17 de mayo de 1650, Inocencio X, por medio de un breve dirigido al inquisidor general, condenó el indulto de D. João IV ${ }^{50}$. El tribunal percibió claramente que este breve no solucionaba el problema pues cabía la posibilidad de que D. João IV, pese a la resolución del pontífice, decidiese no suspender el albalá de 1649. En realidad, los ministros del Santo Oficio temían llegar a la ruptura abierta con la corona, pues eran conscientes de que "depende totalmente o Santo Officio do favor dos principes, e que sem elle e muito menos contra sua vontade não se podera bem conservar sua authoridade e exercicio" ${ }^{51}$. Pero, aun así, el inquisidor general y el Consejo no retrocedieron y, el 15 de diciembre, D. Francisco de Castro, acompañado por fray João de Vasconcelos y por Pantaleão Rodrigues Pacheco, se presentó ante D. João IV. Aunque el rey les advirtió de que, bajo ningún concepto, consentiría que ejecutasen el breve, el inquisidor general declaró ante el monarca que no podía dejar de obedecer la resolución papal ${ }^{52}$.

Tras la entrevista con D. João IV, los ministros del tribunal temieron, no sin motivo, una respuesta violenta del monarca a la desobediencia de la Inquisición, de modo que tanto el inquisidor general como los diputados se prepararon ante el eventual ataque de la corona. Ello explica una resolución del Consejo tan drástica y sin precedentes como la del 29 de diciembre de 1650. Ante la sospecha de que, por algún motivo, D. Francisco de Castro fuese apartado de los diputados, éstos acordaron que el propio inquisidor general suspendiese la jurisdicción del Consejo para que, sin él, no pudiese despachar ningún negocio. ¿Qué temían personajes de la talla y experiencia política de fray João de Vasconcelos, Pedro da Silva de Faria, Francisco Cardoso de Torneo, Sebastião César de Meneses, Pantaleão Rodrigues Pacheco o Diego de Sousa? Probablemente en la mente de todos ellos estaba la no tan lejana prisión de Castro entre 1641 y 1643 y pensaban, quizás, que D. João IV desearía apartarlo del

47 BNP, FG, cód. 1538, fols. 276r-279r: Consultas de los tribunales de Coimbra (sin fecha) y de Évora (30 de julio de 1649).

48 BNP, FG, cód. 1538, fols. 280r-287v: Consulta de la Inquisición de Lisboa (3 de agosto de 1649).

49 ASV, SS, Portogallo, $n^{\circ} .1^{\text {a }}$, fol. 178r: Carta de D. Francisco de Castro a Inocencio X del 17 de octubre de 1649 .

50 Breve de Inocencio X del 16 de mayo de 1650, publicado en $C D P$, tomo XIII, pp. 186-187.

51 BNP, FG, cód. 1538, fols. 300r-300v: Consulta del tribunal de Coimbra (3 de noviembre de 1650). Cf. Ibidem, fols. 301r-303r: Consultas del tribunal de Évora (sin fecha) y de Lisboa (15 de noviembre de 1650).

52 BNP, FG, cód. 1536, fols. 283r-285v: Fala que fes Sua Magesdade ao senhor bispo inquisidor geral mandandoo hir a sua prezença... 
Santo Oficio para conseguir que éste se plegase a los intereses de la corona. Por ello, los diputados decidieron adelantarse y renunciar a toda su jurisdicción en manos del inquisidor general cuya vida, como se había demostrado a raíz de la conjura de 1641, era intocable ${ }^{53}$. Un mes más tarde, el 26 de enero de 1651, el Consejo General ordenaba a todos los inquisidores del reino que prendiesen con secuestro de bienes a las personas acusadas de herejía sin respetar el albalá de 1649 que había sido derogado por el breve de $1650^{54}$. El mismo día, D. Francisco de Castro encargaba a los inquisidores que, en adelante, le comunicasen a él mismo los asuntos de que, conforme al Regimento, debían dar cuenta al Consejo. Ahora bien, en el caso de que no pudiesen, por cualquier motivo, acceder al inquisidor general, éste les retiraba su jurisdicción ${ }^{55}$.

El colofón de este conflicto abierto entre D. João IV y D. Francisco de Castro fue el albalá del 26 de octubre de 1655, por el que el monarca retiraba al inquisidor general la administración de los bienes confiscados a los herejes y la transfería al Conselho da Fazenda ${ }^{56}$. A pesar de que, durante buena parte del período filipino, el Santo Oficio había temido, a veces con motivo, que la corona privase al inquisidor general de la administración del fisco, los Austrias no habían llegado nunca a dar un paso tan radical. Pero ahora la nueva dinastía -en principio mucho más débil-se decidía a adoptar un arbitrio que llevaba años amenazando a la Inquisición.

Sin embargo, a pesar de las profundas desavenencias surgidas entre el Santo Oficio y la corona durante los últimos años de vida de D. João IV, ambos poderes siguieron presentándose en público como aliados. Un ejemplo evidente son los autos de fe. Los reyes asistieron al que se celebró en Lisboa el 11 de octubre de 1654 y el predicador, fray António das Chagas, de la Orden de San Francisco, dedicó el sermón, una vez impreso, a doña Luisa de Guzmán. En la prédica no faltaron las habituales alabanzas al tribunal y sus ministros pero ahora más hiperbólicas que nunca. Fray António comparó al Santo Oficio con la antigua arca de la alianza, encargado, como estaba, de guardar la nueva ley de Cristo y los ministros del tribunal fueron asimilados a los espíritus angélicos ${ }^{57}$.

\section{La muerte del rey y del inquisidor general}

En la década de 1650 se produjo un relevo generacional en el gobierno tanto del Santo Oficio como del reino: en 1652 moría fray João de Vasconcelos, decano del Consejo, en 1653 D. Francisco de Castro, inquisidor general, y en 1656 el propio D. João IV.

53 ANTT, TSO, CG, liv. 346, fols. 27v-28r: Asiento del Consejo General del 29 de diciembre de 1650.

54 ANTT, TSO, CG, liv. 348, fol. 20v: Orden del Consejo General del 26 de enero de 1651. Ese mismo día, el Consejo General elevó una consulta a D. João IV en la que exponía que había ordenado proceder contra los sospechosos de herejía como hasta entonces, de decir, con secuestro de bienes. Conocemos el contenido de esta consulta gracias al edicto del Consejo del 18 de enero de 1657.

55 BNP, FG, cód. 1536, fol. 288r: Orden del inquisidor general del 26 de enero de 1651.

56 Publicado por Silva, J. J. de A.: Collecção Chronologica da Legislação Portuguesa, Lisboa, Imprensa de F. X. de Sousa, 1856, tomo VII, p. 382.

57 A Rainha Nossa Senhora, offerece este Sermão o P.M. Fr. Antonio das Chagas, da Ordem de S. Francisco, Lisboa, na officina craesbeeckiana, 1654, pp. 44-45. 
Como decimos, el 29 de enero de 1652 fallecía fray João de Vasconcelos, diputado del Consejo General en el lugar reservado a la Orden de Santo Domingo y firme colaborador de D. Francisco de Castro. Recordemos que había sido el propio Castro quien lo había nombrado consejero. Además, Vasconcelos había sido prior del convento de Santo Domingo de Bemfica, en cuya iglesia Castro construyó una soberbia capilla para que sirviese de panteón de su familia. En 1636, cuando se debatían en Madrid unos arbitrios en los que se proponía retirar al inquisidor general la administración de los bienes confiscados, D. Francisco de Castro envió a Madrid a fray João de Vasconcelos para defender los intereses de la Inquisición. Mientras se encontraba en la corte, estallaron las revueltas de 1637 en el Alentejo y el Algarbe. Felipe IV le envió a Évora para que intentase sofocar la rebelión pero, según parece, fray João fracasó debido a la desconfianza de los sublevados y a la falta de colaboración por parte de la nobleza local ${ }^{58}$. Cuando murió fray João de Vasconcelos, D. Francisco de Castro ofició la misa de cuerpo presente, en la que estuvieron también los obispos electos de Coimbra, Sebastião César de Meneses, de Leiria, Diogo de Sousa e Castro, y de Elvas, Pantaleão Rodrigues Pacheco, los tres diputados del Consejo General. El propio inquisidor general costeó las honras fúnebres celebradas en el convento de Santo Domingo de Lisboa una semana después del fallecimiento de Vasconcelos y a las que asistió junto con todos los ministros, oficiales y familiares del Santo Oficio que residían en Lisboa ${ }^{59}$.

No había trascurrido aún un año desde la muerte de fray João de Vasconcelos, cuando el Santo Oficio perdió al inquisidor general. El 29 de diciembre de 1652, D. Francisco de Castro recibía la extremaunción. Cuando esta noticia llegó a Évora, el tribunal del Santo Oficio decidió organizar una procesión rogativa por la salud del inquisidor general ${ }^{60}$. Pero las súplicas de la Inquisición de Évora llegaron tarde. Apenas había comenzado el día 1 de enero de 1653, cuando D. Francisco de Castro moría en su habitación del palacio de los Estaus de Lisboa ${ }^{61}$. A pesar de la crisis del poder inquisitorial o precisamente por ello mismo, el Santo Oficio organizó solemnísimas exequias en los tres tribunales peninsulares. La ceremonia en Évora tuvo lugar los días 31 de enero y 1 de febrero en la iglesia de Santo Domingo. El inquisidor Manuel de Magalhães de Meneses ofició la misa y predicó el padre fray António Vel, calificador del Santo Oficio. En Coimbra, el tribunal celebró las exequias, como era habitual, en el convento de Santa Cruz, el día 13 de enero, y en ellas predicó el padre jesuita Nuno da Cunha. Ese mismo día, tenían lugar las que organizaron el Consejo General y el tribunal de Lisboa en el convento de Santo Domingo, en las que predicó fray Manuel Ferreira ${ }^{62}$.

\footnotetext{
58 Sobre esta cuestión, vid. López-SAlazAr CoDEs, op. cit. (nota 5), pp. 329-330.

59 Ferrer de Valdecebro, fray A. (O.P.): Historia de la vida del V.P.M.F. Juan de Vasconcelos de la Orden de Predicadores, Madrid, por doña María Rey viuda de Diego Díaz de la Carrera, s.a. (¿1669?), fols. 88v-92r.

60 BNP, FG, cód. 1529, fols. 31r-32v: Forma da proçisão que fez a Inquisição de Evora pella saude do Illmo. Sr. Bispo Dom Francisco de Castro inquisidor geral.

61 Coelho, A. B.: A Morte do Inquisidor-Geral, Lisboa, Caminho, 2007, pp. 11-32.

62 BNP, FG, cód. 1529, fols. 196r-197r: Exequias que fez a Inquisição de Evora pella alma do Illmo. Sr. Bispo Inquisidor Geral Dom Francisco de Castro. Los tres sermones predicados en Lisboa, Coimbra y Évora en esta ocasión fueron publicados bajo el título Oraçoens funebres nas exequias que o tribunal do Santo
} 
Tras la muerte de D. Francisco de Castro, D. João IV decidió nombrar inquisidor general a su propio hijo, el infante D. Afonso, en ese momento un niño de 9 años de edad. Como era de esperar, el Santo Oficio recibió esta noticia con satisfacción, pues venía a demostrar el vínculo entre la Inquisición y la corona y hacía recordar los tiempos en los que el tribunal había sido regido por miembros de la familia real, como el cardenal infante D. Henrique y el cardenal archiduque Alberto. No obstante, la muerte del príncipe D. Teodósio, el 15 de mayo de 1653, echó por tierra este proyecto, pues D. Afonso se convirtió entonces en el heredero al trono ${ }^{63}$.

Según parece, hubo algún inquisidor que intentó utilizar la muerte de D. Teodósio y la debilidad de D. João IV en los últimos momentos de su vida. Si hemos de dar crédito a lo que diría en varias ocasiones don Francisco de Sousa Coutinho, Sebastião César de Meneses, diputado del Consejo General, y D. Manuel da Cunha, capelãomor y antiguo diputado del mismo Consejo, habrían atribuido la muerte del príncipe a la oposición de D. João IV a aceptar que el papa nombrase obispos motu proprio y no a presentación real ${ }^{64}$. También don Francisco de Sousa Coutinho refería que, cuando D. João IV estaba agonizando, en noviembre de 1656, el capelão-mor se presentó ante él e intentó que sintiese escrúpulos de conciencia por haber firmado el albalá de exención de las confiscaciones. Para el embajador: "atrevimento grande foi com tão poucas letras como as suas hir em ora semilhante meter em escrupulos a quem com tão bizarra rezolução e dezapego se tinha entregue a morte" ${ }^{65}$.

\section{La regencia de doña Luisa de Guzmán y el gobierno del Consejo}

Tras la muerte de D. João IV, la reina doña Luisa de Guzmán se hizo cargo de la regencia debido a la minoría de edad de D. Afonso VI. Dentro del nuevo grupo dirigente destacaban, especialmente, D. Francisco de Faro, conde de Odemira y presidente del Conselho Ultramarino, y D. António Luís de Meneses, conde de Castanhede y vedor da fazenda, así como Pedro Vieira da Silva, secretario de Estado, y Gaspar de Faria Severim, que estaba al frente de la Secretaría de las Mercedes ${ }^{66}$.

Por lo que respecta al Tribunal de la Fe, tras la muerte de D. Francisco de Castro el Consejo General se ocupó del gobierno del Santo Oficio, tal y como ordenaba el Regimento ${ }^{67}$. Conviene detenernos en la composición del Consejo durante este turbulento período. En enero de 1653 estaba integrado por personas que habían ingresado en él tanto en tiempos de los Austrias como durante el reinado de D. João IV. Así,

Officio fez ao Illustrissimo, \& Reverendissimo Senhor D. Francisco de Castro, inquisidor geral destes Reynos, \& senhorios, do Conselho de Estado de S. Magestade, Lisboa, Officina Craesbeckiana, 1654.

63 ANTT, TSO, CG, liv. 160, fol. 82v: Registro de correspondencia del Consejo General a la Inquisición de Coimbra (15 de marzo de 1653). Agradezco sinceramente a la profesora Fernanda Olival que me proporcionase esta referencia.

64 Cartas de don Francisco de Sousa Coutinho a doña Luisa de Guzmán, del 13 de agosto de 1657, y al conde de Odemira, del 11 de mayo de 1658, publicadas en $C D P$, tomo XIII, pp. 450-456 y 499-502.

65 Carta de don Francisco de Sousa Coutinho a doña Luisa de Guzmán de 1657 (sin mes ni día), publicada en $C D P$, tomo XIII, pp. 434-441.

66 XAVIER y CARDIM, op. cit. (nota 5), p. 89.

67 BNP, FG, cód. 1529, fol. 33r: Carta del Consejo General al tribunal de Évora del 2 de enero de 1653. 
Pedro da Silva de Faria, Francisco Cardoso de Torneo y Sebastião César de Meneses habían entrado en el organismo rector del Santo Oficio en 1635 y 1636. Por el contrario, Pantaleão Rodrigues Pacheco y Diogo de Sousa e Castro lo habían hecho en 1641 y 1642, respectivamente. Por último, en 1653 fray Pedro de Magalhães, O.P., había pasado a ocupar el lugar reservado a la Orden de Santo Domingo, vacante por la muerte de fray João de Vasconcelos.

Durante la regencia de doña Luisa de Guzmán se produjeron varios cambios dentro del Consejo. Según el conde de Ericeira, en 1654 Sebastião César de Meneses, obispo electo de Coimbra, y su hermano, el franciscano fray Diogo de Meneses, habrían sido encarcelados en el fuerte del palacio real lisboeta, acusados de confidentes de Castilla ${ }^{68}$. Ahora bien, de acuerdo con un memorial presentado muchos años más tarde por el propio César de Meneses, su prisión habría durado desde marzo de 1653 hasta mayo de 1661 y habría tenido lugar en la casa del noviciado de la Compañía de Jesús ${ }^{69}$. Sin embargo, según el conde de Ericeira, Sebastião César de Meneses desempeñó el cargo de secretario de la nobleza en las cortes de Lisboa reunidas tras la muerte del príncipe D. Teodósio en mayo de $1653^{70}$. Además, en agosto de ese mismo año, seguía participando en el Consejo General ${ }^{71}$. Pero en abril de 1654 su nombre ya no aparece entre las firmas de los acuerdos de este organismo ${ }^{72}$. Por lo tanto, la prisión de Sebastão César de Meneses debió producirse en marzo de 1654 y no de 1653 , como él dijo ${ }^{73}$. Cuando D. João IV eligió a Manuel de Saldanha para sustituirle como obispo de Coimbra, el Consejo General decidió también proveer el lugar del diputado que había quedado vacante por su encarcelamiento. El elegido resultó ser Luís Álvares da Rocha, inquisidor de Lisboa, que ingresó en el Consejo en enero de 1656. Además, en la primera mitad del año de 1657 murieron los dos últimos diputados procedentes del período filipino: Pedro da Silva de Faria y Francisco Cardoso de Torneo ${ }^{74}$. Por ello, en abril de 1657 fue nombrado diputado Pedro de Castilho, sobrino del inquisidor general homónimo. Y en junio de 1660, tras la muerte de Castillo, ingresaron en el Consejo Álvaro Soares de Castro y Manuel de Malhagães de Meneses, procedentes del tribunal de Lisboa.

\footnotetext{
68 Matos, op. cit. (nota 18), pp. 53-85. Meneses, op. cit. (nota 27), tomo I, p. 823.

69 ANTT, TSO, CG, liv. 346, fols. 31A-31B: Memorial de Sebastião César de Meneses y asiento del Consejo General del 11 de agosto de 1662.

70 Meneses, op. cit. (nota 27), tomo I, p. 802.

71 Participó, junto a Pedro da Silva de Faria, en una junta de dos diputados del Consejo y dos desembargadores del Paço reunida para resolver un problema de jurisdicción (ANTT, TSO, CG, liv. 346, fols. 29r-29v).

72 ANTT, TSO, CG, liv. 346, fol. 30r: Asiento del Consejo General del 21 de abril de 1654.

73 En el libro 12 de la Colecção São Vicente se encuentra las órdenes para que los doctores Francisco de Carvalho, Diogo Marchão Temudo y Martim Monteiro registrasen la casa de Sebastião César de Meneses y la celda de fray Diogo César de Meneses y confiscasen todos sus papeles. Están fechadas el día 26 de marzo, pero no se especifica de qué año. ANTT, Colecção São Vicente, liv. 12, fol. 333.

74 En marzo de 1657, Francisco Cardoso de Torneo pasaba a ocupar el cargo honorífico de inquisidor da corte, en sustitución de Pedro da Silva de Faria. En julio de ese mismo año, Pantaleão Rodrigues Pacheco sucedía a Cardoso de Torneo. ANTT, TSO, CG, liv. 136, fols. 163r y 164v: Copias de las provisiones de inquisidor da corte para Francisco Cardoso de Torneo (16 de marzo de 1657) y para Pantaleão Rodrigues Pacheco (10 de julio de 1657).
} 
El inicio de la regencia de doña Luisa de Guzmán estuvo marcado por el incremento de la tensión entre el Santo Oficio y la corona, ahora mucho más débil. Apenas había muerto D. João IV cuando, el 23 de noviembre de 1656, el Conselho de Estado elevaba una consulta a la regente sobre el gobierno del reino. Entre otros aspectos, el Conselho se oponía firmemente al albalá de exención de confiscaciones y al decreto regio por el que D. João IV había encomendado al Conselho da Fazenda la administración de los bienes confiscados ${ }^{75}$. Por su parte, el propio Conselho da Fazenda, en consulta del 2 de enero de 1657, constataba que el albalá era nulo, pues había sido condenado por el Sumo Pontífice ${ }^{76}$. Finalmente, el 18 de enero de 1657, el Consejo General publicaba un edicto en el que declaraba que todos los que hubiesen apoyado el decreto de 1649 impedían el ministerio del Santo Oficio y, por lo tanto, exhortaba a que fuesen denunciados en la Inquisición ${ }^{77}$.

A partir de julio de 1657, Pantaleão Rodrigues Pacheco, decano del Consejo, se convirtió en el personaje de mayor importancia política dentro del Santo Oficio. Sabemos que la regente lo castigó, aunque desconocemos el modo en que lo hizo. Francisco de Sousa Coutinho, embajador en Roma, aconsejó a la reina que le privase del obispado de Elvas y que fuese desposeyendo de sus mitras al resto de inquisidores ${ }^{78}$. En su pulso con la corona, el Santo Oficio pudo contar con dos firmes apoyos en la corte: Pedro Vieira da Silva, secretario de Estado, y D. Miguel da Cunha, capelãomor. Este último debía gran parte de su ascenso político y eclesiástico al paso por el Santo Oficio, en el que había ingresado en 1620 como diputado del tribunal de Coimbra. Tres años más tarde era ya inquisidor de Lisboa y en 1632 accedía al Consejo General, por provisión del entonces inquisidor general D. Francisco de Castro. Finalmente, en 1636, Felipe IV lo nombró obispo de Elvas y, ya tras la Restauración, se convirtió en capelão-mor de D. João IV.

Pero el Santo Oficio también tenía sus propios enemigos y no era el menor de ellos el nuevo embajador en Roma. En 1655 había sido enviado a la Santa Sede Francisco de Sousa Coutinho con el objetivo principal de que el papa reconociese a D. João IV como rey legítimo de Portugal y resolviese la cuestión de los obispados vacantes. Desde el primer momento, Sousa Coutinho dirigió duras críticas contra el Tribunal de la $\mathrm{Fe}$ al que consideraba un serio enemigo de la autoridad real y un aliado de los pontífices en su pulso con la corona portuguesa. "O Papa sabe muito bem, ou pello menos cuida que ha de ter a Inquizição a seu favor" decía en carta dirigida a D. João IV y, poco después, advertía a la regente de que la Inquisición era "tão perigoza em Portugal que se lhe não acode com remedio prompto he bastante para arruinarnos"79. Pero Coutinho no sólo criticaba abiertamente la actividad política de los inquisidores

75 BNP, PBA, cód. 738, fols. 76-82. Esta consulta fue publicada por Prestage, E.: O Conselho de Estado. D. João IV e D. Luísa de Gusmão, Lisboa, Arquivo Histórico Português, 1919.

76 BNP, PBA, cód. 738, fols. 25r-29r. La consulta fue publicada por Prestage, E.: “Tres consultas do Conselho da Fazenda de 1656 a 1657', Revista de História, 34 (1920), pp. 1-26.

77 El edicto del Consejo General del 18 de enero de 1657 está publicado en SiLvA, J. J. de A.: op. cit. (nota 56), tomo IX, pp. 230-233. Cf. AzEvedo, op. cit. (nota 40), p. 276.

78 Carta de Francisco de Sousa Coutinho a doña Luisa de Guzmán de 1657 (sin mes, aunque probablemente de mayo, junio o julio), publicada en CDP, tomo XIII, pp. 434-441.

79 Cartas de don Francisco de Sousa Coutinho del 28 de julio de 1656 y de 1657 (sin mes ni día), publicadas en $C D P$, tomo XIII, pp. 320-329 y 434-441. 
sino que cuestionaba la misma utilidad del Tribunal de la Fe. Así, dudaba de que el objetivo del Santo Oficio portugués fuese la reducción de los herejes al gremio de la Iglesia, pues tenía puestas las miras en las haciendas de los condenados y no en catequizarlos ${ }^{80}$.

\section{El reinado de D. Afonso VI: la búsqueda de un inquisidor general}

El 22 de junio de 1662, D. Afonso VI decidía hacerse cargo personalmente del gobierno del reino. Abríase ahora un período en el que el poder recaería en el triunvirato constituido por D. Luís de Vasconcelos e Sousa, conde de Castelo Melhor, D. Jerónimo de Ataíde, conde de Atouguia, y Sebastião César de Meneses. Al mismo tiempo, fueron apartados del monarca algunos personajes que habían ocupado el centro de la escena política durante la regencia de doña Luisa de Guzmán. Así, el duque de Cadaval, enemigo de Castelo Melhor, fue desterrado de la corte y Pedro Vieira da Silva fue sustituido por António de Sousa de Macedo al frente de la secretaría de Estado ${ }^{81}$.

Como no podía ser de otro modo, también se produjeron transformaciones en el Santo Oficio. Cuando D. Afonso comenzó a gobernar, el Consejo General estaba integrado por Pantaleão Rodrigues Pacheco, Diogo de Sousa, fray Pedro de Malhagães, Luís Álvares da Rocha, Álvaro Soares de Castro y Manuel de Magalhães de Meneses $^{82}$. Aunque doña Luisa de Guzmán había puesto en libertad a Sebastião César de Meneses, éste no había regresado al Consejo y su lugar de diputado había sido ocupado por Álvares da Rocha. La mayoría de edad de Afonso VI supuso la vuelta de César de Meneses a la escena política ${ }^{83}$. Cuando el rey lo nombró arzobispo de Lisboa, en julio de 1662, Meneses elevó un memorial al Consejo General en el que solicitaba que le fuese restituido su cargo de diputado o, al menos, que se le jubilase. Aunque el Consejo consideró que no podía acceder a sus peticiones, decidió otorgarle una pensión anual de 400.000 réis que percibiría en tanto no tomase posesión del arzobispado de Lisboa ${ }^{84}$.

Como sabemos, el Santo Oficio se encontraba sin inquisidor general desde la muerte de D. Francisco de Castro en 1653. Diez años después, D. Afonso VI decidió proveer este oficio y escogió para él a Sebastião César de Meneses, arzobispo electo de Lisboa. El 5 de enero de 1663, el secretario António de Sousa de Macedo le comunicaba la merced real. El monarca encargó al padre Gaspar de Gouveia, asistente de la Compañía de Jesús en Roma, que tratase este asunto con Alejandro VII ${ }^{85}$. Asimismo,

\footnotetext{
${ }^{80}$ Carta de Francisco de Sousa Coutinho a doña Luisa de Guzmán del 13 de agosto de 1657, publicada en $C D P$, tomo XIII, pp. 450-456.

81 XAVIER y CARDIM, op. cit. (nota 5), pp. 130-138 y 165-169.

82 ANTT, TSO, CG, liv. 346, fol. 30v: Asiento del Consejo General del 28 de abril de 1661.

83 Según unas noticias que llegaron a Madrid, D. Afonso VI había hecho una petición a la nobleza y Sebastião César de Meneses había contribuido con 10.000 ducados. BNE, mss. 2389, fol. 140r: Noticias que vinieron de Lisboa a 9 de julio de 1662.

84 ANTT, TSO, CG, liv. 346, fols. 31A-31B: Memorial de Sebastião César de Meneses y asiento del Consejo General del 11 de agosto de 1662.

85 Cartas de D. Afonso VI a Alejandro VII y al cardenal Orsini, protector de Portugal, (sin fecha), publicadas en $C D P$, tomo XIV, pp. 28-30.
} 
pidió al padre Giovanni Paolo Oliva, que gobernaba de facto la Compañía debido a la enfermedad del general Goswino Nickel, que ayudase al jesuita portugués ${ }^{86}$. Según parece, la corte de Lisboa esperaba que la Santa Sede accediese a este nombramiento sin dificultad puesto que en los breves de provisión de los inquisidores generales no se aludía a la presentación real sino que el papa utilizaba la fórmula motu proprio.

La noticia de que D. Afonso deseaba nombrar inquisidor general a César de Meneses llegó también a Madrid. Probablemente fue el cardenal don Pascual de Aragón quien comunicó esta novedad, pues sabemos que a finales de año pedía instrucciones a Felipe IV sobre cómo debía actuar en este asunto ${ }^{87}$. En España, hubo quien aconsejó al monarca que tratase de impedir el nombramiento. Así, por ejemplo, un tal fray José de Lencastre, probablemente portugués, consideró que el papa designaría inquisidor general al eclesiástico que propusiese el Braganza y que, por ello, no desempeñaría el oficio "con el celo con que gobiernan aquel tribunal los Inquissidores del Consejo Supremo que siguen los exemplares del ultimo Inquisidor General Don Francisco de Castro y de fray Juan de Vasconcelos" 88 . Sin embargo, Felipe IV debía confiar bastante en Sebastião César de Meneses, "uno de los sugetos que en diferentes ocasiones ha estado preso y sido mortificado por afecto a mi servicio". Por ello, el monarca ordenó al cardenal de Aragón que no interviniese en este asunto ni tratase de impedir la expedición del breve de provisión para el cargo, siempre que fuese -como era costumbre- motu proprio $^{89}$.

Desde el establecimiento de la Inquisición en Portugal, el oficio de inquisidor general había recaído casi siempre en un obispo consagrado. A partir del reinado de $\mathrm{Fe}-$ lipe III, para solventar el problema de la residencia de los prelados, se había impuesto la costumbre de que el elegido para el cargo de inquisidor general renunciase a su iglesia. Así habían hecho D. Pedro de Castilho, obispo de Leiria, D. Fernão Martins Mascarenhas, del Algarbe, y D. Francisco de Castro, de Guarda. Es decir, todos los inquisidores generales portugueses habían sido siempre obispos, si bien desde Castilho se trató de eméritos. Como diría D. Afonso VI, la dignidad episcopal había estado siempre aneja al cargo de inquisidor general "por sua grande preheminencia, authoridade e jurisdição nas materias da fee" ${ }^{90}$. Ahora bien, los papas nunca habían confirmado a César de Meneses en ninguna de las prelacías para las que había sido presentado por los monarcas lusos y, en consecuencia, no había sido tampoco consagrado. Por ello, D. Afonso pidió a Alejandro VII que nombrase a Sebastião César de Meneses arzobispo de Fez, por lo tanto, de anillo. En Portugal, el monarca ordenó a Pantaleão Rodrigues Pacheco, diputado del Consejo General, y al padre Nuno da Cunha, de la Compañía de Jesús, que estudiasen si podía admitir la provisión de esta

\footnotetext{
86 ANTT, Colecção São Vicente, liv. 12, fols. 318 y 325: Cartas de D. Afonso VI a Gaspar de Gouveia y a Giovanni Paolo Oliva, vicario general de la Compañía de Jesús (sin fecha).

87 BNE, mss. 11263 ${ }^{18}$ : Resumen de tres cartas del cardenal Aragón tocantes a la provisión de las Yglesias de Portugal con fecha de 20 de noviembre de 1663.

88 BNE, mss. 11083, fols. 1r-7v: Papel de fray José de Lencastre a don Luis de Aranguren. Cf. ValLadares, op. cit. (nota 4), p. 243.

89 AMAAEE, EESS, leg. 70, fols. 377-379: Carta de Felipe IV al cardenal don Pascual de Aragón del 11 de diciembre de 1663.

90 ANTT, Colecção São Vicente, liv. 12, fol. 318: Carta de D. Afonso VI a Gaspar de Gouveia, asistente de la Compañía de Jesús en Roma (sin fecha).
} 
iglesia motu proprio. Ambos eclesiásticos coincidieron en que, puesto que la mitra de Fez no era de patronato real, podía admitirse el nombramiento de César de Meneses con dicha fórmula ${ }^{91}$. Por su parte, Felipe IV ordenó al cardenal Aragón que tratase de impedir que el papa concediese al inquisidor general el arzobispado de Lisboa a presentación de D. Afonso VI. A cambio, el monarca español proponía que el papa otorgase a Meneses un arzobispado in partibus que no fuese de patronato real ${ }^{92}$. Por lo tanto, como vemos, las cortes de Lisboa y de Madrid parecían estar de acuerdo en que Sebastião César de Meneses pasase a desempañar el cargo de inquisidor general con la dignidad arzobispal.

Sin embargo, la propia evolución política de la corte de Lisboa determinó que el cargo de inquisidor general permaneciese vacante. En realidad, el Consejo General nunca había mirado con buenos ojos el nombramiento de Sebastião César de Meneses. En 1662 este organismo había vetado su reingreso en el Santo Oficio y en 1663 recibió con bastante desconfianza la noticia de su elección como inquisidor general. D. Afonso VI dispuso que, hasta que llegase el breve de nombramiento, Meneses regresase al Consejo para desempeñar su cargo de diputado y pasase a residir en el palacio de los Estaus, en los aposentos de los inquisidores generales ${ }^{93}$. Por ello, los diputados temieron que el monarca le ordenase gobernar el Santo Oficio antes de tener el breve y acordaron oponerse con todas sus fuerzas a ello. No obstante, para tranquilizar los ánimos, Meneses se comprometió a no encargarse del gobierno de la Inquisición sin contar con el nombramiento papal ${ }^{94}$. Pero el fin de su carrera política estaba cerca. El 22 de mayo de 1663 el ejército español entraba en Évora. Cuando en Lisboa se supo la entrega de la ciudad, estalló un motín popular. Una de las casas saqueadas fue, precisamente, la de Sebastião César de Meneses, al que se acusaba de confidente del Rey Católico.

La conquista de Évora por las tropas de don Juan José de Austria vino a demostrar hasta qué punto las fidelidades de unos y otros eran cambiantes. El ayuntamiento, el cabildo catedralicio y el tribunal inquisitorial escribieron a Felipe IV para manifestarle su satisfacción por la toma de la ciudad. En este momento, el Santo Oficio de Évora estaba formado por Manuel Corte Real de Abranches, D. João de Melo y Pedro Mexia de Magalhães, que firmaron la carta dirigida al monarca ${ }^{95}$. Sin embargo, a pesar de esta ostentación de fidelidad, las relaciones entre el tribunal inquisitorial y las autoridades militares españolas fueron muy conflictivas. De hecho, parece ser que el tribunal escribió tal carta a Felipe IV por orden del propio D. Juan de Austria ${ }^{96}$. Y

\footnotetext{
91 BPE, cód. CxxII/18, fols. 128 y ss: Memorial de Pedro Cezar de Meneses sobre seu tio Sebastião Cezar de Menezes, publicado por Matos, op. cit. (nota 18), pp. 69-77.

92 AMAAEE, EESS, leg. 70, fols. 380r-381r: Carta de Felipe IV al cardenal don Pascual de Aragón del 23 de diciembre de 1663 .

93 ANTT, Colecção São Vicente, liv. 12, fol. 306r: Billete de António de Sousa de Macedo a Sebastião César de Meneses del 5 de enero de 1663.

94 ANTT, TSO, CG, liv. 346, fols. 32r-32v: Asiento del Consejo General el 9 de enero y declaración del secretario Diogo Velho del 10 de enero de 1663.

95 BNE, mss. 2390, fol. 291: Carta de la Inquisición de Évora a Felipe IV del 24 de mayo de 1663.

96 BA, cód. 51-IX-33, fols. 408-419: Copia de huma carta que o Senhor Bispo estando na Arrabida escreveo ao Senhor D. Pedro seu irmão (sin fecha). Según don João de Melo, la carta que escribió la Inquisición a Felipe IV fue interceptada por el ejército portugués.
} 
el enfrentamiento abierto entre los militares y los ministros del Santo Oficio no tardó en estallar. El 13 de junio por la mañana, la caballería española cercaba las calles colindantes con la Inquisición y los soldados de infantería tomaban el patio del tribunal, mientras el maestre de campo don Pedro de Fonseca detenía al inquisidor Manuel Corte Real. Se le acusaba de traidor y de recibir y enviar avisos al ejército portugués. De hecho, cuando le registraron apareció en su bolsillo un escrito del maestre de campo Fernão Mascarenhas en el que le pedía que intentase amotinar al pueblo de Évora contra la guarnición que había dejado don Juan de Austria. Tras esto, el maestre de campo don Pedro de Fonseca decidió registrar, por la fuerza, las cárceles inquisitoriales para averiguar si había armas o gente escondidas y si los inquisidores habían intentado utilizar a los presos para luchar contra los españoles. Poco después, el gobernador español, D. Francisco Gattinara, conde de Sertirana, se presentó en el tribunal y ordenó encarcelar al inquisidor Corte Real en el convento de Santo Antão y al solicitador del Santo Ofício, al tesorero y al meirinho del fisco y al meirinho del tribunal en distintos acuartelamientos. Lo extraño de todo este asunto no es que el gobernador recelase de la fidelidad del Santo Oficio a Felipe IV sino la actitud del inquisidor D. João de Melo. Poco después de que su compañero fuera detenido y las cárceles registradas, Melo entraba en el tribunal junto al propio Sertirana y le acompañaba en una nueva inspección, ahora mucho más pacífica, a las cárceles y a la llamada cámara del secreto del Santo Oficio. Parecía, pues, que el inquisidor estaba dispuesto a colaborar con las autoridades españolas ${ }^{97}$.

En realidad, la situación de Melo era extremadamente complicada en estos momentos, si hemos de dar crédito a un relato de lo sucedido en la Évora ocupada que él mismo escribió años más tarde ${ }^{98}$. Inmediatamente después de la capitulación de la ciudad, D. João de Melo hizo un viaje a Lisboa con el pretexto de que necesitaba tratar algunos asuntos del Santo Oficio con el Consejo General. Pero en la corte, Melo se entrevistó con el conde de Castelo Melhor y con el marqués de Marialva y a su vuelta a Évora se convirtió en espía del gobierno luso, al que enviaba y del que recibía avisos, y se encargó de organizar la resistencia al ejército castellano. Así, repartió dinero entre los soldados extranjeros que habían servido a Portugal, para evitar que se uniesen al ejército de don Juan de Austria. Además, cuando el bastardo real, para ganarse el apoyo del pueblo, prometió la supresión de todos los nuevos tributos creados durante los años anteriores, Melo intentó convencer a los habitantes de que el dominio castellano sería, a la larga, más gravoso. Más aún: ordenó colocar carteles públicos en los que D. Afonso VI prometía mercedes a los soldados del ejército español que se uniesen a sus tropas. Y encargó a los religiosos en cuyos conventos se alojaba el ejército que intentasen ganarse a los oficiales para que abandonasen el servicio del Rey Católico. En realidad, D. João de Melo no estaba desempeñando este

97 ANTT, TSO, IE, proc. 7547: Sumario que se fes de mandado dos senhores inquisidores sobre vexaçoes que cometeo o mestre de campo de intanteria espanhola Dom Pedro de Afonsequa.

98 BA, cód. 51-IX-33, fols. 408r-419r: Copia de huma carta que o Senhor Bispo estando na Arrabida escreveo ao Senhor D. Pedro seu irmão ( $\sin$ fecha). Ya el profesor Valladares subrayó la importancia de este documento para comprender lo ocurrido Évora durante la ocupación por las tropas de don Juan José de Austria. Cf. Valladares, op. cit. (nota 4), pp. 253-255. Según creemos, D. João de Melo estuvo en Lisboa entre el 28 y el 31 de mayo. 
papel dirigente en Évora porque, como inquisidor, se considerase en la obligación de encabezar la resistencia. Su comprometida actitud se entiende sólo si se tienen en cuenta sus vínculos familiares y sociales. A diferencia de sus compañeros Corte Real y Mexia de Malhagães, Melo pertenecía a una de las familias más prestigiosas de la ciudad de Évora. Así, su padre, D. Jorge de Melo, y su abuelo, D. António de Melo eran, según se decía en la época, "dos mais principais fidalgos desta terra". Pero, si estrechos eran sus vínculos con la ciudad alentejana, no lo eran menos con la corona, pues su padre, D. Jorge de Melo, había servido en las casas de D. João IV y de doña Luisa de Guzmán ${ }^{99}$.

Cuando, en la mañana del 13 de junio, el gobernador español llamó urgentemente a D. João de Melo, no es de extrañar que nuestro inquisidor temiera que se hubiesen descubierto sus maniobras y los avisos que enviaba a la corte de Lisboa. Por lo tanto, resulta bastante lógico que considerase mucho más conveniente aparentar colaboración con el gobernador español y abrirle la cámara del secreto en la que, por cierto, sabía que no había más que los procesos inquisitoriales que poco o nada podían interesarle. Probablemente, el inquisidor prefirió que registrasen esta sala -la más secreta de todo el tribunal- en vez de que inspeccionasen su propia casa, donde sí había documentos comprometedores. Además, tal vez consideró más conveniente permitir que el gobernador buscase armas entre los procesos que dar lugar a una nueva inspección a las cárceles. Sabemos que el maestre de campo don Pedro de Fonseca no había registrado todos los corredores donde se encontraban los presos y que, precisamente, en uno de ellos los ministros del tribunal habían escondido armas y pólvora ${ }^{100}$. Como explicó Melo en la relación enviada más tarde a su hermano:

os guardas tinhão recolhido de algúns seos amigos muitas armas, porque os castelhanos lhas não tomassem como fazião a todos os moradores por quanto mandavão por publico pregão que os que tiveçem armas as levasem ao seu armazem, e metendosse estas em dous carçeres com muita polvora e bala só neste se não fes aquella diligença que nos mais fazião por descobrir armas.

Ahora bien, ¿cómo había llegado a oídos de las autoridades españolas que algunos ministros del Santo Oficio estaban organizando la resistencia dentro de la ciudad? Como hemos dicho, tras la capitulación de Évora, Melo había viajado a Lisboa y allí había recibido instrucciones del monarca, del conde de Castelo Melhor y del marqués de Marialva. De regreso a Évora, el inquisidor entregó a su compañero en el Santo Oficio, Manuel Corte Real, una carta de Castelo Melhor en la que le ordenaba que ayudase a Melo. Pero Corte Real no supo actuar con la discreción y prudencia necesarias: repartió dinero entre militares del ejército español para que se uniesen al portugués, con tan mala suerte que éstos lo denunciaron ante el gobernador de la

\footnotetext{
99 ANTT, TSO, CG, Habilitações, maço 105, diligência 1763: D. João de Melo. La cita está extraída de la declaración de António Fernandes Viegas.

100 Gracias a las declaraciones de António Coelho y Lourenço Barreto, guardas de la cárcel del tribunal de Évora, sabemos que don Pedro da Fonseca no llegó a registrar todos los corredores. Por ello no descubrió las armas que allí se escondían: "e feita esta diligencia nos carceres de sima, descerão aos corredores debaxo e a fiserão tambem em todos os carceres dos presos excepto os que estão no corredor novo de fora aonde não chegarão". ANTT, TSO, IE, proc. 7547.
} 
plaza. Por ello, tanto el gobernador como el maestre de campo pensaron que el agente de Lisboa en Évora era Manuel Corte Real y no D. João de Melo.

Si la situación de los dos inquisidores era complicada, no resultaba más sencilla la del propio tribunal de Évora. Dependiente del Consejo General del Santo Oficio portugués, se encontraba ahora en territorio ocupado por las tropas de Felipe IV. Necesitaba consultar constantemente multitud de asuntos con el Consejo pero en este momento, debido a la toma de la ciudad, la comunicación con el organismo supremo resultaba extremadamente complicada. Por ello, tras la capitulación, el Consejo pensó en enviar a Évora al diputado Luís Álvares da Rocha para que, con los inquisidores de ese distrito, concluyese los procesos. Hecho esto, los ministros y oficiales, los documentos del secreto y los presos condenados a relajación deberían trasladarse a Lisboa. Sin embargo, D. Afonso VI y Castelo Melhor consideraron que era más conveniente no retirar el tribunal inquisitorial de Évora y esperar a que la ciudad fuese reconquistada. Por ello, el 29 de mayo de 1663, el Consejo General acordó que la jurisdicción del tribunal de Lisboa se extendiese al territorio de Évora mientras durase la ocupación de la ciudad por las tropas españolas ${ }^{101}$. Además, el Consejo ordenó a los inquisidores de Évora que concluyesen los procesos y publicasen las sentencias a los reos dentro del propio tribunal. Por ello, durante todo el mes de junio, coincidiendo con la ocupación española, los inquisidores despacharon decenas de causas cuyas sentencias fueron leídas en autillos en la sala del tribunal ${ }^{102}$. En realidad, del análisis de estos procesos se desprende que el Santo Oficio estaba intentando vaciar sus cárceles, pues los inquisidores los concluyeron apresuradamente. Veamos un par de ejemplos significativos. El reo André Afonso había ingresado en la cárcel del tribunal de Évora el 2 de noviembre de 1662. Sin embargo, los inquisidores no tuvieron con él la primera audiencia hasta dos meses más tarde, el 19 de enero de 1663. Cinco meses transcurrieron entre esta primera sesión y la segunda, que tuvo lugar el 18 de junio de 1663. Sin embargo, ahora sólo pasaron dos días entre esta segunda audiencia y la tercera y otros dos días después, el 22 de junio de 1663, el tribunal concluyó el proceso. El 23, Afonso oía su sentencia y ese mismo día era puesto en libertad. En el caso de João Fanqueiro, esta conclusión apresurada resulta todavía más evidente. Preso en las cárceles inquisitoriales desde abril de 1660, su proceso se desarrolló lentamente

101 Como consecuencia, hubo dos mujeres de la circunscripción de Évora que se presentaron a confesar sus culpas en el tribunal lisboeta. Se trata de Ana Semedo y Maria Semedo, moradoras en Estremoz, cuyos procesos fueron remitidos del tribunal de Lisboa al de Évora en abril de 1664. ANTT, TSO, CG, liv. 348 , fol. 25r: Orden del Consejo General del 29 de mayo de 1663. Ibidem, fols. 25r-25v: Orden del Consejo General del 25 de abril de 1664. Cf. ANTT, TSO, IE, proc. 6110 (Ana Semedo) y proc. 9840 (Maria Semedo).

102 António Joaquim Moreira, en su lista de los autos de fe celebrados en las tres Inquisiciones peninsulares, incluyó uno que habría tenido lugar en Évora el 23 de junio de 1663, es decir, durante la ocupación española, y en el que habrían comparecido 142 personas. Desconocemos de dónde extrajo Moreira la información sobre este supuesto auto que, de hecho, nunca se celebró. Quizás vio alguna lista de las personas sentenciadas por el tribunal de Évora en junio de 1663 y llegó a la conclusión de que habrían comparecido en una ceremonia pública. Así por ejemplo, en la Biblioteca da Ajuda se conserva una "Lista das pessoas que sairão da Inquisiçam de Evora em (espacio) de (espacio) de 1663". Al final de esta relación está escrito: “A gente conteúda nesta lista sahio da Inquisisam este anno presente estando D. João de Austria senhor desta cidade de Évora". BA, cód. 49-IV-15, fols. 4r-7v. Cf. Moreira, op. cit. (nota 36), parte II. 
durante casi tres años. Sin embargo, en junio de 1663, todo cambió: el 22 fue interrogado de nuevo y ese mismo día el tribunal se reunió para sentenciar su causa ${ }^{103}$.

La ocupación de Évora por las tropas de Felipe IV duró hasta el 24 de junio. Sin embargo, los problemas del Santo Oficio y las desavenencias entre el tribunal y los jefes del ejército -ahora el portugués- continuaron. Antes de que las tropas de don Juan José de Austria abandonasen Évora, el tribunal ordenó la prisión de don Pedro de Fonseca, el maestre de campo que había entrado violentamente en las cárceles inquisitoriales. Esto generó un enfrentamiento entre los inquisidores y el general portugués don Sancho Manuel de Vilhena, conde de Vila Flor. Éste consideró que el encarcelamiento del maestre de campo español contravenía lo acordado en la capitulación de la ciudad y ordenó al inquisidor D. João de Melo que lo pusiese en libertad. Además, amenazó con prender a Manuel Corte Real y a Pedro Mexia de Magalhães y con acusarles de traidores, por haber firmado la carta que el tribunal escribió a Felipe IV en la que le profesaba fidelidad y que, como sabemos, cayó en manos del ejército portugués. En realidad, lo que se produjo no fue más que un choque entre dos mentalidades contrapuestas: la del militar, que había empeñado su palabra en el acuerdo de rendición y que estaba dispuesto a permitir la salida de los soldados españoles a toda costa, y la del inquisidor, defensor acérrimo de la jurisdicción del tribunal apostólico al que consideraba superior a cualquier poder temporal. El militar se comportó con fanfarronería: "disse que naquelle negocio não queria ja admittir partido, porque elle naquella occasião hera Papa e tinha quatorse mil infantes para mandar prender e soltar a quem quisesse". Y el inquisidor respondió con altivez que "o avaliar as culpas porque este Tribunal mandava prender a elle somente tocava e que a ninguém mais hera licito intrometerse nesta materia senão obedecer ao que o Santo Offício mandava por ser sempre o mais ajustado" ${ }^{104}$. Probablemente para evitar enfrentamientos, el Consejo General ordenó que no se tratase más de este asunto y, en consecuencia, el tribunal de Évora no tuvo más remedio que liberar a don Pedro de Fonseca ${ }^{105}$.

La pérdida y recuperación de Évora afectó igualmente a los organismos de gobierno del Santo Oficio, esto es, al inquisidor general y al Consejo. Como hemos dicho, cuando se tuvo noticia en Lisboa de la rendición de la ciudad, el pueblo se amotinó y saqueó varios palacios, entre ellos el del arzobispo, donde residía entonces Sebastião César de Meneses. Tras la reconquista de Évora, el conde de Vila Flor remitió a Lisboa los papeles de la secretaría de don Juan José de Austria que, según parece, evidenciaron las relaciones entre el inquisidor general y el bastardo ${ }^{106}$. El día 11 de julio, se reunió en el palacio real una junta, integrada por D. Afonso VI, el conde de Castelo Melhor, el de Vila Flor y los desembargadores del Paço Jorge da Silva Mascarenhas, Pedro Fernandes Monteiro y Fernão de Matos de Carvalhosa. Estos ministros acordaron que se ordenase a César de Meneses abandonar la corte. Por ello,

\footnotetext{
103 ANTT, TSO, IE, proc. 7492 (André Afonso) y proc. 2836 (João Fanqueiro). Este cambio en el ritmo de desarrollo de la causa se aprecia igualmente en el resto de procesos sentenciados en este momento.

104 BA, cód. 51-IX-33, fols. 408r-419r: Copia de huma carta que o Senhor Bispo... (fol. 418r).

105 ANTT, TSO, IE, proc. 7547 (Pedro da Fonseca).

106 Valladares, op. cit. (nota 4), pp. 256-258. Matos, op. cit. (nota 18), pp. 64-65.
} 
el arzobispo electo de Fez se retiró al convento de los franciscanos de Loures, al norte de Lisboa ${ }^{107}$.

El Consejo General, que nunca había aceptado de buena gana la elección de César de Meneses para el oficio de inquisidor general, aprovechó la situación para intentar evitar que se expidiese la bula de su nombramiento. Así, los diputados elevaron una consulta al monarca en la que pedían que le depusiese de este cargo. Alegaban que, si había otro motín popular y César de Meneses era inquisidor general, el Santo Oficio se exponía a que las masas asaltasen el palacio de los Estaus ${ }^{108}$. Además, escribieron a Alejandro VII para darle cuenta de la trayectoria política de Meneses. De forma bastante abierta, el Consejo solicitó al papa que no lo nombrase inquisidor general. El párrafo final de esta carta resulta más que ilustrativo:

Ésta es, Beatísimo Padre, la situación en que se encuentra el asunto; ésta, la condición de Sebastião César. Si su elección para tan notable oficio resulta útil al servicio divino y al decoro y tranquilidad del tribunal o no, fácilmente Vuestra Santidad podrá juzgarlo con su habitual prudencia. Nosotros sólo deseamos conseguir de la Santa Sede Apostólica un superior que no sea indigno de sus predecesores, que engrandecieron en extremo esta sede con la integridad de las costumbres, con el esplendor de la sangre y con la doctrina de las ciencias y que proporcionaron a los súbditos una recta norma de vida y ejemplo. Dios Optimus Maximus ilumine la inteligencia de Vuestra Beatitud y encamine sus acciones con el habitual esclarecimiento de su Espíritu Santo ${ }^{109}$.

En realidad, el Consejo General estaba tomando partido por el conde de Castelo Melhor, el hombre fuerte tras la desintegración del triunvirato. De hecho, Sebastião César de Meneses siempre achacó su destierro a las tensiones con el nuevo valido ${ }^{110}$. Además, estaba enemistado con Pantaleão Rodrigues Pacheco, Diogo de Sousa y fray Pedro de Magalhães, los tres diputados más antiguos del Consejo, a quienes acusó de haber escrito al rey y al papa para que anulasen su nombramiento con el único motivo de "satisfazer ao valido" 111 . Por lo tanto, tras la reconquista de Évora, el interés de Castelho Melhor pasaba a coincidir con el de los ministros más poderosos del Tribunal de la Fe.

107 MacÊdo, A. de S. de: D. Afonso VI, edición e introducción de Eduardo Brazão, Oporto, Livraria Civilização, 1940, pp. 158-160.

108 No hemos encontrado esta consulta pero conocemos su contenido de forma indirecta. Cf. BA, cód. 50-V-37, $\mathrm{n}^{\circ}$ 1: Memorial de Sebastião César de Meneses al regente D. Pedro.

109 BA, cód. 46-IX-17, fols. 223v-226v: Carta del Consejo General a Alejandro VII del 24 de julio de 1663 (la traducción del latín al castellano es nuestra). Esta carta fue presentada al papa el 3 de octubre de 1663.

110 Mientras Castelo Melhor conservó el poder, Sebastião César de Meneses insistió en profesar su amistad con él. Así, en diciembre de 1663, declaraba, en una carta dirigida a D. Afonso VI, "a amisade e fe que guardei em todo o tempo ao Conde de Castel Melhor". Sin embargo, cuando el infante don Pedro asumió el poder, César de Meneses no dudó en manifestar su desacuerdo con el anterior gobierno. ANTT, Colecção São Vicente, liv. 12, fols. 310-311: Carta de Sebastião César de Meneses a D. Afonso VI del 13 de diciembre de 1663. BA, cód. 50-V-37, nº 7: Carta de Sebastião César de Meneses al padre Manuel Fernandes, S.J., del 28 de enero de 1669.

111 BA, cód. 50-V-37, nº. 1: Memorial de Sebastão César de Meneses (sin fecha, pero de 1668). 


\section{La paz con la Monarquía Hispánica}

Sin inquisidor general, el Consejo, encabezado por Pantaleão Rodrigues Pacheco, siguió gobernando el Santo Oficio durante el final de la guerra de Restauración. Y, como era de esperar, sus ministros no permanecieron al margen de las intrigas políticas de la corte de Lisboa. En septiembre de 1667, caía el conde de Castel Melhor y el 21 de noviembre la reina María Francisca de Saboya se refugiaba en un convento y pedía la anulación de su matrimonio con D. Afonso VI. Fue precisamente Pantaleão Rodrigues Pacheco uno de los jueces de esta causa. Sin embargo, antes de que quedase concluida, falleció Pacheco, en diciembre de $1667^{112}$. Le sucedía al frente de la Inquisición, como decano del Consejo, otro de los hombres que habían participado en el golpe del 1 de diciembre de 1640: Diogo de Sousa e Castro ${ }^{113}$.

En 1668, dos nuevos diputados pasaron a formar parte del Consejo General: Alexandre da Silva y Francisco Barreto. Resulta muy interesante comprobar que las relaciones de este último con el Santo Oficio se remontaban a tiempos de los Austrias. Francisco Barreto pertenecía a una familia vinculada tradicionalmente, desde tiempos de los Felipes, al servicio a la Inquisición. Su tío, también llamado Francisco Barreto, había sido diputado del Consejo General y obispo del Algarbe desde 1636. Además era hermano del también inquisidor Manuel Corte Real de Abranches, hijos ambos de Roque da Costa Barreto, familiar del Santo Oficio ${ }^{114}$.

Con la firma de la paz entre Portugal y la Monarquía Hispánica se solucionó el problema de la provisión de los obispados ${ }^{115}$. Era, además, el momento de elegir un nuevo inquisidor general pues, como sabemos, el cargo se encontraba vacante desde la muerte de D. Francisco de Castro en 1653. El escogido resultó ser D. Pedro de Lencastre, duque de Aveiro ${ }^{116}$. Sin embargo, esta decisión del regente no dejó de plantear problemas, debido a la oposición de Sebastião César de Meneses. Éste alegaba que en 1663 ya había sido presentado a la Santa Sede para ocupar el cargo de inquisidor general y que, por lo tanto, no podía privársele de él sin causa. En el caso de que

112 Los jueces de la causa de la nulidad de la reina fueron D. Francisco Sotomayor, obispo de Targa, el doctor Valentim Feio da Mota, vicario general del arzobispado de Lisboa, y Pantaleão Rodrigues Pacheco. Cuando éste murió, fue sustituido por Antão de Faria da Silva, canónigo de Lisboa y diputado del Santo Oficio. En la sentencia final votaron, además de los anteriores, otros dos ministros del Santo Oficio: Francisco Barreto, diputado del Conselho Geral, y Pedro de Ataíde de Castro, inquisidor de Coimbra. Meneses, op. cit. (nota 27), tomo II, pp. 919-920. MACHADO, op. cit. (nota 39), vol. 3, pp. 511-512.

113 ANTT, TSO, CG, liv. 136, fol. 171r: Copia de la provisión de inquisidor da corte para Diogo de Sousa ( 2 de enero de 1668). En tiempos de Diogo Barbosa Machado se conservaba en la sacristía de la catedral de Lisboa la sepultura de Pantaleão Rodrigues Pacheco con la siguiente inscripción: “Aqui jaz o corpo do Doutor Pantaleão Rodrigues Pacheco que foy conego nesta Santa Sé de Lisboa, e falleceo aos trinta dias do mez de Dezembro de 1667'.

114 Cf. López-Salazar Codes, A. I.: "Familia y parentesco en la Inquisición portuguesa: el caso del Consejo General (1569-1821)", en López-SAlazar CoDEs, A. I.; Olival, F. y FigueirôA-RÊGo, J.: Honra e sociedade no mundo ibérico e ultramarino: Inquisição e Ordens Militares (séculos XVI-XIX), Lisboa, Caleidoscópio, 2013, pp. 129-154.

115 En 1669, la Santa Sede reconocía la independencia de Portugal y el 1 de mayo de 1669 don Pedro nombraba embajador en Roma a D. Francisco de Sousa, conde de Prado. PAIVA, J. P.: "A Igreja e o poder", en AzEvedo, C. M.: História Religiosa de Portugal, II: Humanismos e Reformas, Lisboa, Círculo de Leitores, 2000, p. 163.

116 Hasta el 26 de agosto de 1671 el regente no escribió a Inocencio X para que lo nombrase inquisidor general. ASV, SS, Portogallo, n. 220: Qual'ora vaca in Portogallo... (sin fecha). 
don Pedro prefiriese a otra persona al frente de la Inquisición, César de Meneses reclamaba el arzobispado de Lisboa, para el que había sido presentado en 1662 y al que, en su opinión, no había renunciado salvo con la condición de acceder al cargo de inquisidor general. Es más, prometió que, si se le concedía este oficio, renunciaría a asistir a las reuniones del Conselho de Estado para no inmiscuirse en negocios políticos ${ }^{117}$. Podemos aventurar los motivos por los que don Pedro no deseaba que Meneses desempeñase el cargo de inquisidor general. A pesar de que, en 1668, llevaba ya cinco años desterrado y apartado del poder, nadie olvidaba que había sido uno de los principales protagonistas del golpe palaciego de 1663. Y, de manera bastante oportuna, el secretario Pedro Vieira da Silva descubrió un parecer enviado por César de Meneses a D. Afonso VI poco tiempo después de que éste asumiese el gobierno. En ese documento, Meneses abogaba por la reclusión de doña Luisa de Guzmán en un monasterio y por el destierro del duque de Cadaval ${ }^{118}$.

\section{Conclusión: ¿una fortaleza de Castilla?}

El 13 de febrero de 1668, se firmaba el tratado de paz entre España y Portugal que ponía fin a veintiocho años de guerra. Como hemos visto, ni el Santo Oficio como institución ni sus ministros mantuvieron un comportamiento político inmutable durante todo este período. Desde luego, en los primeros años de la Restauración, el Tribunal de la Fe no fue ninguna fortaleza de Castilla. Si durante la década de 1650 hubo quien consideró que la Inquisición era pro-castellana fue por su enfrentamiento con la corona debido a la cuestión de las confiscaciones. En realidad, el Santo Oficio quería conservar su propio poder, fuese bajo el monarca que fuese. Por eso, el problema con el Braganza no surgió en 1640 -a pesar del episodio aislado de la conjura profilipina- sino tras el albalá de 1649 y despareció una vez que doña Luisa de Guzmán suprimió la exención de confiscaciones. Resulta bastante ilustrativo de lo que acabamos de decir el hecho de que, tras el fin de la guerra, buena parte de las mitras recayesen en ministros del Santo Oficio. Así, Diogo de Sousa y D. Veríssimo de Lencastre, diputados del Consejo General, accedieron a los arzobispados de Évora -la iglesia más rica de todo el país-y de Braga, respectivamente. Al mismo tiempo, Francisco Barreto, también miembro de este organismo supremo, pasaba a ocupar el obispado del Algarbe, mientras que el antiguo inquisidor de Évora D. João de Melo recibía la mitra de Elvas ${ }^{119}$.

117 Conforme avanzó el año de 1668, el discurso de Sebastião César de Meneses se fue volviendo cada vez más violento, a medida que perdía las esperanzas de conseguir una mitra o el cargo de inquisidor general. A principios de 1669, escribía al padre Manuel Fernandes, confesor del regente: "me hei de queixar diante de Deos eterno, diante de seu vigario na terra, diante do Padre Geral da Companhia e diante de meus parentes e do mundo todo, que eu sei compor cartas e estampar livros pois ja muitos meus correm pelo mundo todo e em Roma sou por elles mais conhecido que em Portugal”. BA, cód. 50-V-37, nº. 7: Carta de Sebastião César de Meneses al padre Manuel Fernandes del 28 de enero de 1669.

118 En la época se consideraba que Sebastião César de Meneses había elaborado el proyecto para apartar a la reina del palacio real. XAVIER y CARDIM, op. cit. (nota 5), p. 161.

119 Almeida, F. de, História da Igreja em Portugal, Porto-Lisboa, Livraria Civilização, 1968. PAIVA, J. P.: Os Bispos de Portugal e do Império, Coimbra, Imprensa da Universidade, 2006, p. 479. 